\title{
Determination of the diffusion coefficients of small solutes in cheese: A review
}

\author{
Juliane Floury $^{1,2,3 *}$, Sophie Jeanson ${ }^{1,2}$, Samar Aly ${ }^{1,2}$, Sylvie Lortal ${ }^{1,2}$ \\ ${ }^{1}$ INRA, UMR1253, F-35000 Rennes, France \\ 2 AGROCAMPUS OUEST, UMR1253, F-35000 Rennes, France \\ ${ }^{3}$ Université Européenne de Bretagne, France
}

Received 6 July 2009 - Revised 15 December 2009 - Accepted 2nd February 2010

Published online 30 March 2010

\begin{abstract}
In cheese technology, the mass transfer of small solutes, such as salt, moisture and metabolites during brining and ripening, is very important for the final quality of the cheese. This paper has the following objectives: (i) to review the data concerning the diffusion coefficients of solutes in different cheese types; (ii) to review the experimental methods available to model the mass transfer properties of small solutes in complex matrices such as cheese; and (iii) to consider some potential alternative approaches. Numerous studies have reported the transfer of salt in cheese during brining and ripening. Regardless of the type of cheese and its composition, the effective diffusion coefficients of salt have been reported to be between 1 and $5.3 \times 10^{-10} \mathrm{~m}^{2} \cdot \mathrm{s}^{-1}$ at $10-15^{\circ} \mathrm{C}$. However, few papers have dealt with the mass transfer properties of other small solutes in cheese. Most of the reported effective diffusion coefficient values have been obtained by macroscopic and destructive concentration profile methods. More recently, some other promising techniques, such as nuclear magnetic resonance, magnetic resonance imaging or fluorescence recovery after photobleaching, are currently being developed to measure the mass transfer properties of solutes in heterogeneous media at microscopic scales. However, these methods are still difficult to apply to complex matrices such as cheese. Further research needs to focus on: (i) the development of nondestructive techniques to determine the mass transfer properties of small solutes at a microscopic level in complex matrices such as cheese; and (ii) the determination of the mass transfer properties of metabolites that are involved in enzymatic reactions during cheese ripening.
\end{abstract}

\section{cheese / mass transfer / diffusion / modelling / solute}

\begin{abstract}
摘要 - 干酪中少量溶质扩散系数的测定-综述。在干酪技术中, 通过盐渍和成熟过程的控 制来调整少量溶质 (盐、水分和代谢产物) 的传质, 将对最终干酪的质量具有非常重要的 作用。本文综述了溶质在不同类型干酪中的扩散系数, 以及综述了少量溶质在干酪这一复 杂基质中质量传递的数学模型。关于盐渍和成熟过程盐的迁移已有大量的文献报道, 无论 是何种类型的干酪, 盐的有效扩散系数在 $1 \sim 5.3 \times 10^{-10} \mathrm{~m}^{2} \cdot \mathrm{s}^{-1}\left(10 \sim 15^{\circ} \mathrm{C}\right)$ 范围内。但是 关于干酪中其他少量溶质传质特性的报道非常有限。大多数的有效扩散系数是通过显微镜 或者破坏性浓度分布曲线的方法获得。一些新的测定技术，如核磁共振、磁共振成像或者光 脱色荧光恢复技术等已经在显微技术的水平下用于测定不同介质中溶质的质量传递特性。然 而, 这些技术还很难应用于象干酪这样复杂的介质中。将来的研究将主要在：(i) 基于干酪 这一复杂介质, 在显微水平下采用非破坏性分析技术测定少量溶质的质量传递性质; (ii) 测 定干酪成熟过程中代谢产物的质量传递特性。
\end{abstract}

\section{干酪 / 质量传递 / 扩散 / 模型 / 溶质}

*Corresponding author (通讯作者): Juliane.Floury@agrocampus-ouest.fr 
Résumé - Détermination des coefficients de diffusion de petits solutés dans le fromage : une synthèse. En technologie fromagère, le transfert de petits solutés, tels que le sel, l'eau et les métabolites au cours du saumurage et de l'affinage, joue un rôle majeur sur la qualité finale du fromage. Cette revue bibliographique a pour objectifs principaux : (i) de faire le bilan des valeurs publiées des coefficients de diffusion de différents solutés dans les fromages ; (ii) de passer en revue les méthodes expérimentales disponibles pour déterminer les propriétés de transfert des petits solutés dans des milieux complexes comme le fromage ; (iii) de considérer les méthodes alternatives potentiellement applicables aux fromages. Dans la littérature, de nombreuses études ont été publiées au sujet du transfert de sel dans les fromages au cours du saumurage et de l'affinage. En fonction du type de fromage et de sa composition, les coefficients de diffusion effectifs du sel sont compris entre 1 et $5,3 \times 10^{-10} \mathrm{~m}^{2} \cdot \mathrm{s}^{-1}$ à des températures comprises entre 10 et $15^{\circ} \mathrm{C}$. Très peu d'études concernant les propriétés de transfert d'autres petits solutés dans les fromages ont été publiées. La plupart des coefficients de diffusion effectifs ont été obtenus à l'aide de la méthode classique dite « des profils de concentration », méthode macroscopique présentant l'inconvénient d'être destructive. D'autres techniques, telles que la résonance magnétique nucléaire, l'imagerie par résonance magnétique ou la redistribution de fluorescence après photo-blanchiment sont actuellement développées pour mesurer des propriétés de transfert de matière de solutés à une échelle microscopique. Cependant, elles sont encore difficilement applicables aux matrices complexes comme le fromage. Les perspectives en matière de recherche dans ce domaine sont donc les suivantes : (i) le développement de nouvelles techniques expérimentales pour modéliser à l'échelle microscopique les propriétés de transfert de solutés dans des milieux complexes comme le fromage ; (ii) la détermination des propriétés de transfert des métabolites impliqués dans les réactions enzymatiques pendant l'affinage du fromage.

fromage / transfert de matière / diffusion / modélisation / soluté

\section{INTRODUCTION}

In cheese, transport of water and aqueous solutes has a crucial role during cheese making and cheese ripening $(\mathrm{NaCl}$, transfer of substrates or reaction products like lactic acid). Cheese ripening is the result of bacterial activity of immobilized colonies in the lipoproteic matrix. Substrates have to diffuse in the matrix to reach bacterial colonies, and produced metabolites have then to diffuse from the bacterial colonies into the proteinic network. In case of diffusional limitations, microgradients of concentration, $\mathrm{pH}$ or water activity can be created around and in between the immobilized colonies, modifying bacterial and enzymatic activities.

Diffusion properties of cheese solutes can depend on (i) their physicochemical characteristics and (ii) the composition and microstructure of the matrix. In food matrices and notably in cheese, transfers of small molecules can occur between two heterogeneous phases of the matrix, heterogeneous in terms of composition or physical state (liquid, solid or gaseous). To measure these transfers, diffusion coefficients $(D)$ must be modelled [80].

Analysis of the literature reveals a strong lack of data concerning the migration rates of key molecules in cheese, such as sugars, organic acids and peptides, which can be decisive in the ripening process. Most of the data related to mass transport of small solutes in cheese deal with the salting process. Indeed, salt concentration distribution is an important parameter affecting cheese quality and acceptability. Salt affects the water activity of cheese, the growth and survival of bacteria and the activity of cheese enzymes [7].

Many different mechanisms can be involved during cheese processing, like multicomponent diffusion of solutes and water during salting. Due to technical difficulties to follow solute migration and modelling 
difficulties inherent to the physical model chosen, working out diffusion properties of solutes is a complicated task, especially in complex heterogeneous matrices like cheese.

After a theoretical reminder concerning mass transfer phenomena, this paper reviews different methods available in the literature to determine diffusion coefficients of small solutes in cheese products. Values of the diffusion coefficients are then discussed for solutes in different cheese types, with details concerning the modelling methods. Finally, alternative techniques potentially applicable to cheese are presented.

\section{THEORY OF MASS TRANSFER}

\subsection{Definitions}

Mass transfer by diffusion is the transport of molecules caused by a random molecular motion in a region where composition gradient exists [82].

\subsubsection{Steady-state diffusion}

In a macroscopic, motionless (without internal movement and deformation), homogeneous (made up of one phase) and isotropic medium (uniform structure in all directions), solutes diffuse in the direction of their decreasing chemical potentials, until thermodynamic equilibrium is reached. Fick's first law links the diffusive flux to the concentration field, by postulating that the flux goes from high-concentrated regions to low-concentrated regions, with a magnitude that is proportional to the concentration gradient (spatial derivative). In one spatial dimension, this leads to

$$
J_{i}=-D_{i m} \cdot \frac{\partial C_{i}}{\partial x}
$$

where $J_{i}$ is the molar diffusion flux of component $i\left(\mathrm{~kg}\right.$ or $\left.\mathrm{mol} \cdot \mathrm{s}^{-1} \cdot \mathrm{m}^{-2}\right), C_{i}$ is the concentration of component $i$ ( $\mathrm{kg}$ or $\left.\mathrm{mol} \cdot \mathrm{m}^{-3}\right), x$ is the position $(\mathrm{m})$ and $D_{i m}$ is the diffusion coefficient of component $i$ in the medium $\left(\mathrm{m}^{2} \cdot \mathrm{s}^{-1}\right) . J_{i}$ measures the amount of substance that will flow through a small area during a short time interval.

The driving force for the one-dimensional diffusion is the quantity $-\frac{\partial C_{i}}{\partial x}$. To solve transfer equations, a simplification is generally made, considering chemical potential as a concentration or partial pressure (in the gas phase).

In two or more dimensions, the gradient operator $\nabla$ can be used. This leads to

$$
J_{i}=-D_{i m} \cdot \nabla C_{i}
$$

Molecular diffusion coefficient $D_{i m}$ at a constant temperature may be adequately predicted in very diluted solutions using the well-known Stokes-Einstein equation, provided the molecular radius of the solute, solvent viscosity and absolute temperature are known [19]:

$$
D_{i m}=\frac{k_{\mathrm{B}} T}{6 \pi \mu R_{0}},
$$

where $k_{\mathrm{B}}$ is the Boltzmann constant $\left(1.38 \times 10^{-23} \mathrm{~J} \cdot \mathrm{mol}^{-1} \cdot \mathrm{K}^{-1}\right), T$ is the absolute temperature $(\mathrm{K}), \mu$ is the viscosity of the phase $(\mathrm{Pa} \cdot \mathrm{s})$ and $R_{0}$ is the radius of the diffusing molecule $(\mathrm{m})$.

The Stokes-Einstein equation (equation (3)) does not take the intermolecular interactions between solutes and between solvent and solute molecules into account (that may be significant for small solutes). Diffusion through a heterogeneous matrix is more complicated. Solutes will have to diffuse in the liquid or gas phase contained within that porous matrix. Subsequently, the StokesEinstein equation has little use in the prediction of diffusion properties in food [77].

Some phenomena that cannot be distinguished from molecular diffusion must also be considered in heterogeneous matrices in terms of composition and structure, such as 
capillary or Knudsen diffusion, diffusion modification due to matrix changes (obstruction, retraction, etc.) or interactions of the solute with other components. The term "apparent" or "effective diffusion" is then generally preferred to "diffusion" alone. Effective diffusivities are the most convenient way to describe mass transfer process through porous matrices, which have an intricate network of pores where diffusing species take a tortuous path [77].

If we consider liquid diffusion through porous matrices in which the pores are large, Fick's diffusion model is able to correctly describe the mass transfer within the liquid contained in the pores. The flux can be described in terms of an effective diffusion coefficient $D_{\text {eff }}\left(\mathrm{m}^{2} \cdot \mathrm{s}^{-1}\right)$, defined as

$$
D_{\text {eff }}=\frac{\varepsilon}{\tau} D_{i m},
$$

where $D_{i m}$ is the diffusion coefficient of $i$ in the medium $m\left(\mathrm{~m}^{2} \cdot \mathrm{s}^{-1}\right), \tau$ is the tortuosity and $\varepsilon$ is the porosity [82].

In a porous matrix, the effective diffusion coefficient $D_{\text {eff }}$ is then significantly smaller than the molecular diffusion coefficient $D_{i m}$ because of (i) tortuosity effects (the more tortuous the region the more devious the route between two points) and (ii) interactions between the solute and the matrix if they are both charged (ionic strength, hydrophobic and electrostatic interactions) $[69,77]$. Note that equation (4) does not take chemical or electrostatic interactions into account, but only structural incidence of the matrix on solute diffusion properties.

Various alternative equations have been subsequently developed incorporating factors for molecular interactions and physical interferences [67]. To consider charged molecules, a general flux model can be used [38]:

$$
J_{i}=D_{\mathrm{eff}} \frac{C}{R T}\left(\frac{\partial \mu_{i}(x, t)}{\partial x}\right)
$$

where $D_{\text {eff }}$ is the effective diffusion coefficient $\left(\mathrm{m}^{2} \cdot \mathrm{s}^{-1}\right)$, which does not depend on the electrostatic forces. $\mu_{i}$ is the chemical potential of the solute $\left(\mathrm{J} \cdot \mathrm{mol}^{-1}\right)$, which is a function of solute concentration, ionic strength and $\mathrm{pH}$. The charge dependence is thus moved from the diffusion coefficient to the chemical potential. Neglecting pressure and temperature contributions, the chemical potential is defined by [83]

$$
\mu_{i}=\mu_{i}^{0}+R T \ln a+\mu_{e l},
$$

where $a$ is the activity and $\mu_{e l}$ is the contribution of the electrostatic charges to the chemical potential. In dilute solutions, the activity can be replaced by the concentration and if no electrical charges are present, $\frac{\partial \mu_{e l}}{\partial x}=0$, leading to Fick's law according to equation (1).

However, due to the difficulty in quantifying such factors in real food matrices, equation (5) has poor prediction accuracy [77].

\subsubsection{Unsteady-state diffusion}

In order to be able to predict the concentration profiles of solutes in the matrix, Fick's first law is associated to a local mass balance to obtain Fick's second law

$$
\frac{\partial C_{i}}{\partial t}=\nabla\left(D_{i m} \cdot \nabla\left(C_{i}\right)\right) .
$$

Considering both unidirectional mass transfer along the $x$ axis and a constant diffusion coefficient value, the previous equation becomes

$$
\frac{\partial C_{i}(x, t)}{\partial t}=D_{i m} \cdot \frac{\partial^{2}\left(C_{i}(x, t)\right)}{\partial x^{2}} .
$$

Analogous equations can be written in spherical or cylindrical shapes, and two or three dimensions, in order to find the solute concentration as a function of time and position [17]. 


\subsection{Using Fick's law solutions to estimate diffusion coefficients}

Most research publications on mass transfer in cheese are using Fick's model with some specific geometries [10]. Diffusion coefficients in food matrices can be evaluated by different methods involving defined geometries and well-defined experimental conditions (steady or transient state and boundary conditions). To determine the diffusion coefficient of a solute in a given matrix, an experimental device generating a flux of the diffusing substance is set up. An average flux (mass variation) or a profile of concentration of the diffusing substance is measured, using either a destructive (slicing and analyzing samples) or a non-destructive method (nuclear magnetic resonance, NMR; fluorescence recovery after photobleaching, FRAP; radioactive tracer; etc.). A mathematical method, adapted to the experiment and generally based on Fick's laws, gives an average diffusion coefficient or diffusion coefficient versus concentration. Table I presents a summary of the principles, advantages and drawbacks of some existing methods for the determination of diffusion properties in cheese-like matrices.

The majority of macroscopic model studies can be divided into measurements in a diffusion cell (steady-state diffusion type of studies) and in cheese cylinders (transient diffusion type of studies).

\subsubsection{Steady state}

Zorrilla and Rubiolo [88] used the diffusion cell model developed by Djelveh et al. [20]. The diffusion cell consists of two compartments where perfectly mixed solutions $\mathrm{A}$ and $\mathrm{B}$ of equal volume $V$ but different solute concentrations are separated by a matrix slab with thickness $L$ and cross-section $S$. The solute migrates through the slab from the higher concentration solution $\mathrm{A}$ to the lower concentration solution B.

Assuming a one-dimensional diffusion process through the slab and perfectly mixed compartments, the effective diffusion coefficient of the migrating solute can be modelled thanks to Fick's model. Equation (1) is transformed into equation (9) by applying a mass balance, assuming that there is no change in volume and that the effective diffusion coefficient is constant

$$
V_{\mathrm{A}} \frac{\partial C_{\mathrm{A}}}{\partial t}=-D_{\mathrm{eff}} \cdot S \cdot \frac{C_{\mathrm{A}}-C_{\mathrm{B}}}{L},
$$

where $D_{\text {eff }}$ is the effective diffusion coefficient of the solute $\left(\mathrm{m}^{2} \cdot \mathrm{s}^{-1}\right), V_{\mathrm{A}}$ is the liquid volume in the compartment from which the solute diffuses $\left(\mathrm{m}^{3}\right), S$ is the matrix area through which the diffusion takes place $\left(\mathrm{m}^{2}\right)$ and $C_{\mathrm{A}}$ and $C_{\mathrm{B}}$ are the solute concentrations, respectively, in the upper and lower compartments A and B (mol or $\mathrm{kg} \cdot \mathrm{m}^{-3}$ ).

By measuring the solute concentration in the upper compartment $\mathrm{A}$ and, via a mass balance, calculating the concentration in the lower compartment B at different times, an effective diffusion coefficient can be calculated by fitting equation (9) to the experimental data.

\subsubsection{Unsteady or transient state}

Gros and Rüegg [29] reviewed the various experimental techniques and appropriate mathematical treatments proposed to obtain effective diffusion coefficients in food matrices. Measuring unidirectional diffusion from a semi-infinite food cylinder geometry with different boundary conditions is the most frequently applied method to determine the effective diffusion coefficient of a solute in cheese. If the semiinfinite cylinder, containing an initial concentration $C_{0}$ of the solute, is in contact 
Table I. Principles, advantages and drawbacks of existing methods for the determination of effective diffusion properties in cheese-like matrices.

\begin{tabular}{|c|c|c|c|c|c|}
\hline Technique & Principle & Model & Advantages & Drawbacks & Refs. \\
\hline $\begin{array}{l}\text { Infinite cylinder } \\
\text { in contact with } \\
\text { a perfectly mixed } \\
\text { solution }\end{array}$ & $\begin{array}{l}\text { A semi-infinite cylinder } \\
\text { of the matrix, initially } \\
\text { free from the diffusing } \\
\text { solute, is in contact: } \\
\text { - either with a well-stirred } \\
\text { solution containing a } \\
\text { constant concentration } C_{\mathrm{s}} \\
\text { of the solute at the } \\
\text { interface } \\
\text { - or with another semi- } \\
\text { infinite cylinder of matrix } \\
\text { containing a concentration } C_{\mathrm{s}} \\
\text { of the solute }\end{array}$ & 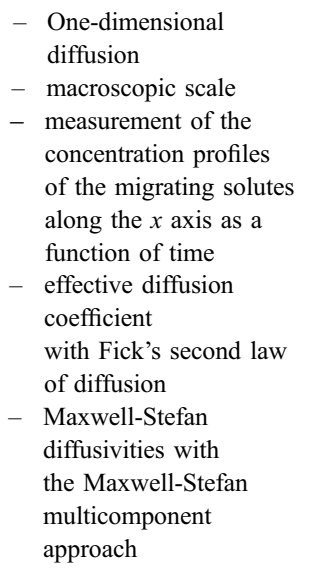 & $\begin{array}{l}\text { - Can be adapted for } \\
\text { various small } \\
\text { molecules } \\
\text { - } \text { easy to implement }\end{array}$ & $\begin{array}{l}\text { - Destructive and low resolution: } \\
\text { thin slicing of the sample } \\
\text { gives spatial resolution } \\
\text { of } 1 \mathrm{~mm} \\
- \text { slow: several days of } \\
\text { diffusion } \\
- \text { a lot of analyses are required } \\
\text { to obtain concentration profiles } \\
\text { as a function of the distance } \\
\text { and the time } \\
- \text { a large number of assumptions } \\
\text { are required when using the } \\
\text { Maxwell-Stefan multicomponent } \\
\text { approach } \\
- \text { lack of physical interpretation } \\
\text { of the Maxwell-Stefan diffusivities }\end{array}$ & $\begin{array}{l}{[29]} \\
{[61]} \\
{[85]} \\
{[23]}\end{array}$ \\
\hline Diffusion cell & $\begin{array}{l}\text { A slab of matrix is placed } \\
\text { in between two compartments } \\
\text { of perfectly mixed solutions } \\
\text { A and B of different solute } \\
\text { concentrations }\end{array}$ & $\begin{array}{l}\text { - One-dimensional } \\
\text { diffusion } \\
\text { - } \text { macroscopic scale } \\
- \text { evaluation of the } \\
\text { solute quantity having } \\
\text { migrated through the } \\
\text { product slab in a } \\
\text { given time } \\
- \text { effective diffusion } \\
\text { coefficient with Fick's } \\
\text { second law of diffusion }\end{array}$ & $\begin{array}{l}\text { - Quite inexpensive } \\
\text { - can be adapted to a } \\
\text { large range of products } \\
\text { - can be adapted to a } \\
\text { multicomponent system } \\
\text { (simultaneous diffusion } \\
\text { of several components) }\end{array}$ & $\begin{array}{l}\text { - Slow: several days of diffusion } \\
\text { - accurate determination of solute } \\
\text { concentrations is required in } \\
\text { both compartments }\end{array}$ & $\begin{array}{l}{[20]} \\
{[89]} \\
{[90]} \\
{[88]}\end{array}$ \\
\hline
\end{tabular}


Table I. Continued.

\begin{tabular}{|c|c|c|c|c|c|}
\hline Technique & Principle & Model & Advantages & Drawbacks & Refs. \\
\hline SL-NVRK & $\begin{array}{l}\text { - Based on the on-line monitoring } \\
\text { of release kinetics of } \mathrm{NaCl} \text { from } \\
\text { a matrix containing a salt } \\
\text { concentration } C_{\mathrm{s}} \text { into water } \\
- \text { a conductivity probe, immersed } \\
\text { in the well-stirred aqueous } \\
\text { solution, continuously measured } \\
\text { the electrolytes released until } \\
\text { thermodynamic equilibrium }\end{array}$ & $\begin{aligned}- & \text { One-dimensional } \\
& \text { diffusion } \\
- & \text { macroscopic scale } \\
- & \text { effective diffusion } \\
& \text { coefficient with Fick's } \\
& \text { second law of diffusion }\end{aligned}$ & $\begin{aligned} &- \text { Non-destructive } \\
&- \text { non-invasive } \\
&- \text { easy and fast } \\
& \text { (no analytical technique } \\
& \text { to quantify } \\
& \text { concentrations) }\end{aligned}$ & $\begin{array}{l}\text { - Lack of specificity of the measure } \\
\text { with the conductivity probe } \\
\text { - } \text { modelling difficulties because } \\
\text { of the two unknown parameters: the } \\
\text { effective diffusion coefficients } \\
\text { of salt and of the other electrolytes } \\
\text { of the product } \\
\text { - can be applied to ionic solutes only }\end{array}$ & $\begin{array}{l}{[46]} \\
{[47]}\end{array}$ \\
\hline PFG-NMR & $\begin{array}{l}\text { - Based on the attenuation of } \\
\text { individual proton resonances } \\
\text { under the influence of linear } \\
\text { field gradients } \\
\text { - the amplitude of the signal is } \\
\text { directly related to the self- } \\
\text { diffusion coefficient of the } \\
\text { molecule }\end{array}$ & $\begin{array}{l}\text { - } \text { Microscopic scale } \\
\text { - } \text { measurement of the } \\
\text { self-diffusion coefficient } \\
\text { of small molecules } \\
\text { (random translational } \\
\text { motion of molecules } \\
\text { driven by internal } \\
\text { kinetic energy) }\end{array}$ & $\begin{array}{l}\text { - No initial gradient } \\
\text { of concentration } \\
- \text { non-destructive } \\
- \text { non-invasive } \\
- \text { promising approach for } \\
\text { characterizing the } \\
\text { structural modifications } \\
\text { during the coagulation } \\
\text { process }\end{array}$ & $\begin{array}{l}\text { - High cost } \\
\text { - } \text { difficulty to sample the product } \\
\text { in the thin NMR tubes } \\
\text { - } \text { high complexity of the spectral data } \\
\text { obtained with real food products } \\
\text { - } \text { difficulty to establish the physical } \\
\text { link between the self-diffusion } \\
\text { coefficient and the effective } \\
\text { diffusivity estimated with } \\
\text { classical methods }\end{array}$ & $\begin{array}{l}{[13]} \\
{[55]} \\
{[56]} \\
{[16]} \\
{[22]}\end{array}$ \\
\hline NMR imaging & $\begin{array}{l}\text { - Imaging technique used primarily } \\
\text { in medical settings to produce } \\
\text { high-quality images of the inside } \\
\text { of the human body } \\
\text { - MRI is based on the principles } \\
\text { of NMR } \\
\text { - MRI primarily images the NMR } \\
\text { signal from the hydrogen nuclei } \\
{ }^{23} \mathrm{Na}-\mathrm{MRI} \text { is based on the } \\
\text { paramagnetic properties of the } \\
\text { naturally occurring }{ }^{23} \mathrm{Na} \text { isotope }\end{array}$ & $\begin{aligned}- & \text { Microscopic scale } \\
- & \text { measurement of the } \\
& \text { self-diffusion coefficient } \\
& \text { of water or Na } \\
- & \text { or visualization of water } \\
& \text { or Na distribution }\end{aligned}$ & $\begin{array}{l}\text { - No initial gradient } \\
\text { of concentration } \\
- \text { non-destructive } \\
- \text { non-invasive }\end{array}$ & $\begin{aligned} &- \text { High cost } \\
&- \text { complex calibration and data } \\
& \text { handling work } \\
&- \text { insensitive technique to } \\
& \text { molecules with low mobility } \\
&- \text { difficulty to establish the physical } \\
& \text { link between self-diffusion } \\
& \text { coefficient and effective diffusivity }\end{aligned}$ & $\begin{array}{l}{[79]} \\
{[78]} \\
{[45]}\end{array}$ \\
\hline
\end{tabular}


Table I. Continued.

\begin{tabular}{|c|c|c|c|c|c|}
\hline Technique & Principle & Model & Advantages & Drawbacks & Refs. \\
\hline FRAP technique & $\begin{array}{l}\text { - A certain region within a } \\
\text { fluorescently labelled sample is } \\
\text { irreversibly photobleached with a } \\
\text { short intense light pulse } \\
\text { - } \text { measurement of the fluorescence } \\
\text { recovery inside the bleached area } \\
\text { as a result of diffusional exchange } \\
\text { of bleached fluorophores by } \\
\text { unbleached molecules }\end{array}$ & 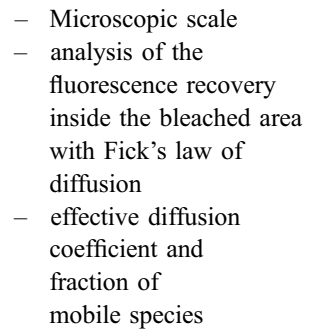 & $\begin{aligned} \text { - } & \text { No initial gradient of } \\
& \text { concentration } \\
- & \text { simple } \\
- & \text { non-destructive and } \\
& \text { slightly invasive }\end{aligned}$ & $\begin{array}{l}\text { - High cost: a CLSM is necessary } \\
\text { - the migrating molecule has to be } \\
\text { fluorescent or it must be marked by } \\
\text { a fluorescent probe } \\
\text { - not adapted to complex and opaque } \\
\text { media like cheese }\end{array}$ & $\begin{array}{l}{[57]} \\
{[14]} \\
{[43]}\end{array}$ \\
\hline
\end{tabular}




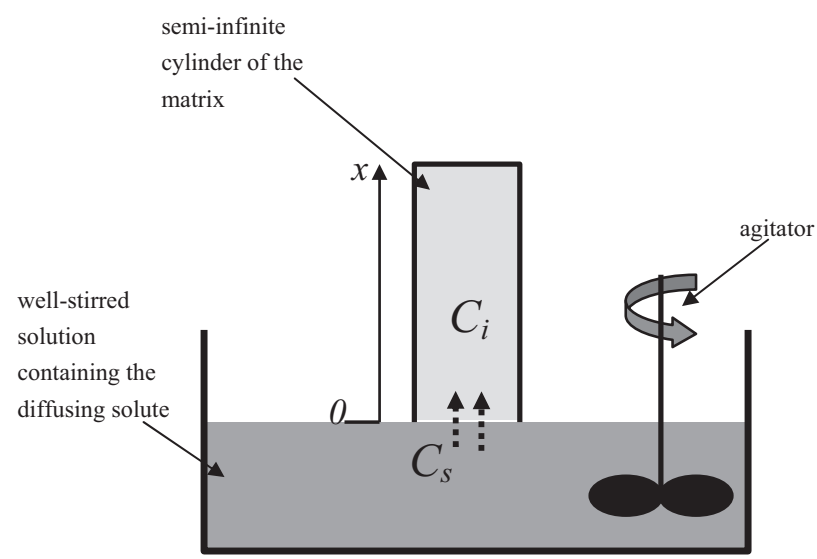

Figure 1. Diagram of the semi-infinite cylinder experimental device.

with a well-stirred solution containing a constant concentration $C_{\mathrm{s}}$ of the solute at the interface $\left(C_{\mathrm{s}}>C_{0}\right)$ (Fig. 1), the external mass transfer resistance can be neglected [71] and the boundary conditions are as follows:

$$
\begin{gathered}
t=0 \quad C_{i}=C_{0} \\
x=0 \quad C_{i}=C_{\mathrm{s}} \text { for } t>0, \\
x \rightarrow \infty \quad C_{i}=C_{0} \text { for } t>0,
\end{gathered}
$$

where $t$ is the time (s), $x$ is the position (m), $C_{i}$ is the concentration of solute $i$ in the matrix $\left(\mathrm{kg}\right.$ or $\left.\mathrm{mol} \cdot \mathrm{m}^{-3}\right), C_{0}$ is the initial concentration of the solute $i$ in the matrix $\left(\mathrm{kg}\right.$ or $\left.\mathrm{mol} \cdot \mathrm{m}^{-3}\right)$ and $C_{\mathrm{s}}$ is the concentration of the same solute at the interface $\left(\mathrm{kg}\right.$ or $\left.\mathrm{mol} \cdot \mathrm{m}^{-3}\right)$.

The duration of experiments is assumed to be such as the solute does not reach the extremity of the matrix. The matrix is thus considered as a semi-infinite medium. This boundary condition is only valid for Fourier number $\left(F_{0}=\frac{D_{\text {eff }} \cdot t}{L^{2}}\right)$ under 0.05 , where $L$ is the length of the semi-infinite cylinder along the $x$ axis $(\mathrm{m})$.

The solution of equation (8) is then

$$
\frac{C(x, t)-C_{0}}{C_{\mathrm{s}}-C_{0}}=\operatorname{erfc}\left(\frac{x}{2 \sqrt{D_{\mathrm{eff}} t}}\right),
$$

where erfc is the complementary error function.

The value of $D_{\text {eff }}$ is then determined from concentration profiles by minimizing the sum of squares of the deviations between the experimental $\left(C_{\text {exp }}\right)$ and model values $\left(C_{\text {model }}\right)$

$$
\text { Crit }=\sum_{i=1}^{N}\left(C_{\text {exp }}-C_{\text {model }}\right)^{2} .
$$

If $F_{0}>0.05$, then the assumption of a semi-infinite medium no longer applies and the last boundary condition must be changed. The solution of equation (8) and its boundary conditions can be found in Crank [17] or in Gros and Rüegg [29].

An alternative method, called the "touching semi-infinite cylinders technique", is based on a similar approach $[29,85]$. 
This method consists in bringing into contact two cylinders of the same matrix, each of them having a different initial concentration of the migrating solutes. The concentration profiles are measured from their distance to the interface, as a function of time, along a one-dimensional axis. Crank [17], Gros and Rüegg [29] or Wilde et al. [85] gave the solution of equation (8) and boundary conditions for this unidirectional diffusion from a semi-infinite matrix cylinder, containing an initially uniform concentration of the diffusing substance into a contiguous semi-infinite cylinder initially free of solute or containing lower concentration.

The main drawback of these types of experiments is that they are generally destructive. Thin slicing of the sample gives spatial resolution of about $1 \mathrm{~mm}$. Some studies are less precise with a slice thickness up to $1 \mathrm{~cm}$ [74]. Moreover, the measurement in each slice of the solute concentration at different given times of the diffusion process is very time-consuming. This explains why such operations are not extensively repeated. In addition, the thinner the slices, the longer the operation and the higher the number of measurements have to be further performed. Reducing the slice thickness also increases uncertainty on the slice position along the direction of transfer and possibly on concentration measurement (due to less matter) [50]. However, these Fickian approaches based on the concentration profiles of the diffusing solute can be adapted for various small molecules, ionized or not, easy to detect and quantify (water, solutes, colourants and aroma compounds) [15].

Lauverjat et al. [47] recently developed a method, also based on the Fickian approach, for easier and faster determination of diffusion properties of salt in complex matrices. This method, called the solid liquid nonvolatile release kinetic method (SL-NVRK), is based on the on-line monitoring of release kinetics of $\mathrm{NaCl}$ from a product containing a salt concentration $C_{\mathrm{s}}$ into water. A conductivity probe, immersed in the wellstirred aqueous solution, continuously measured the electrolytes released until thermodynamic equilibrium. The adjustment of a mechanistic model, ensuing from the analysis of mass transfer to the experimental kinetics, led to the determination of the effective diffusion coefficient of $\mathrm{NaCl}$. However, the main limit is the lack of measurement specificity. Indeed, besides $\mathrm{NaCl}$, the cheese-like model matrices contained other solutes such as $\mathrm{KCl}$, calcium, phosphates, citrates and lactates. Because all these species contribute to the conductivity signal and it was not possible to dissociate the respective contribution of each one, two independent diffusion equations for $\mathrm{NaCl}$ and for other electrolytes were necessary. The main difficulty was that the model had to be adjusted to experimental conductivity data using two unknown parameters, the effective diffusion coefficients of $\mathrm{NaCl}$ and of the other electrolytes. The other drawback is that this method is specific to measuring diffusion properties of ionic species only.

Vestergaard et al. [78] were the first to develop a ${ }^{22}$ Na-radioisotope non-destructive method for studying $\mathrm{NaCl}$ diffusion in meat. Reliable sodium diffusion profiles in meat were obtained by scanning a cylindrical geometry of meat where diffusion of sodium took place from one end to the other end of the cylinder. The use of radioisotopes in the biological and medical sciences is well established. By administering a suitable compound marked with a radioactive tracer it is, for example, possible to locate abnormalities in specific organs. Since the technique was first applied in cancer diagnostics, it has been extensively developed and it is presently known as Single Photon Emission Computerized Tomography.

Despite the disadvantage of the tracer being radioactive and requiring precautions in its handling, Vestergaard et al. [78] concluded that ${ }^{22} \mathrm{Na}$ measurements are a promising methodology for studying salt diffusion 
in meat. This method may be transposed to cheese in order to study the diffusion of salt or other solutes where an atom can be radioactively marked.

\subsubsection{Drawbacks of the Fickian approach}

The classical Fickian approach of transport phenomena is difficult to apply to food matrices because of their specific characteristics, structure, properties, etc. In fact, even considering cheese as a food matrix with saline solution occluded in the pores, parameters such as porosity, tortuosity and phase ratios are not sufficient to describe the mass transfer process accurately. Some typical pitfalls with the Fickian approach in foods were reported by Doulia et al. [21]:

- The dependence of $D_{\text {eff }}$ on the concentration of the component being transferred. In this case, the driving force for mass transfer is the difference in chemical potential and not the difference in concentration.

- The dependence of $D_{\text {eff }}$ on temperature. The application of an Arrhenius-type relation is questionable, in case of sudden changes in the matrix microstructure.

- The dependence of $D_{\text {eff }}$ on volume changes occurring during dehydration (shrinkage) or rehydration (swelling). In most cases, the influence of volume changes is ignored and implicitly included in $D_{\text {eff }}$ value.

- The evaluation of $D_{\text {eff }}$ entails that mass transfer is mainly a molecular diffusion mechanism, whereas several other mechanisms are also often involved, such as capillary or Knudsen diffusion.

- In initial and boundary conditions, the distribution coefficient between the two phases should be taken into account. The latter coefficient is the quotient of the concentrations resulting from the equilibrium experiments and reflects the allegation that the driving force is not the concentration difference. In equilibrium conditions, the distribution coefficient in terms of chemical potential should be equal to 1 .

The perverse effect of calculating a $D_{\text {eff }}$ (which may be correctly defined as a mass transfer coefficient) from experimental data is then that no effort is made to understand the actual mechanism for mass transfer [1]. In fact, some researchers have correctly noted that it is worthless to calculate diffusion coefficients unless the structure is resolved [26]. It is very probable that the quantification of food microstructure using image analysis will assist in finding the mechanisms and their relative contributions to the transport phenomena, and better modelling [1].

In order to improve modelling of mass transfer phenomena in cheese, several other methods were proposed in the literature, which are reviewed thereafter.

\section{MULTICOMPONENT DIFFUSION}

\subsection{Generalized Fick's model}

Zorrilla and Rubiolo [88-90] were the first to develop a model for a multicomponent system (where many components diffuse simultaneously), using the diffusion cell, for determining apparent diffusion coefficients of both $\mathrm{NaCl}$ and $\mathrm{KCl}$ in cheese during salting and ripening processes.

From a theoretical point of view, mass transport phenomena for a multicomponent system can be physically modelled using three different approaches: (i) the generalization of Fick's law, (ii) the use of irreversible thermodynamics and (iii) the use of Stefan-Maxwell equation. These three approaches are based on kinetic, thermodynamic and hydrodynamic considerations, respectively [12].

The generalized Fick's law is, as indicated by its name, a generalization of Fick's 
law initially formulated for binary diffusion [73]. For example, in the case of a ternary mixture, the mass diffusion fluxes $J_{i}^{*}$ $\left(\mathrm{kg} \cdot \mathrm{m}^{-2} \cdot \mathrm{s}^{-1}\right)$ can be calculated from mass fractions of each species $\omega_{i}$ and mass content of the mixture $\rho\left(\mathrm{kg} \cdot \mathrm{m}^{-3}\right)$ using

$$
\left[\begin{array}{c}
\vec{J}_{1}^{*} \\
\vec{J}_{2}^{*}
\end{array}\right]=\rho\left[\begin{array}{ll}
D_{11} & D_{12} \\
D_{21} & D_{22}
\end{array}\right]\left[\begin{array}{l}
\vec{\nabla} \omega_{1} \\
\vec{\nabla} \omega_{2}
\end{array}\right] .
$$

Note that for the third component (arbitrarily chosen as a reference species)

$$
\vec{J}_{3}^{*}=\vec{J}_{1}^{*}-\vec{J}_{2}^{*}
$$

The values of the multicomponent diffusion coefficients $D_{i i}$ (main diffusion coefficients, $\mathrm{m}^{2} \cdot \mathrm{s}^{-1}$ ) and $D_{i j}$ (cross diffusion coefficients, $\mathrm{m}^{2} \cdot \mathrm{s}^{-1}$ ) depend on (i) the reference velocity chosen to express the diffusion velocity of each species with respect to the bulk flow of the mixture (molar, mass or volume average velocity), (ii) the state variable chosen to describe the composition of the system (molar, mass or volume fraction) and (iii) the arbitrary choice made when designing a reference species. This point considerably restricts the use of multicomponent diffusion coefficients found in the literature since these precisions are often lacking. Note that relationships between these coefficients and the binary values are not known a priori [12].

In Zorrilla and Rubiolo [88-90], the generalized Fick's law form was used as a constitutive equation for the diffusive molar flux of $\mathrm{NaCl}$ and $\mathrm{KCl}$ during brining and ripening in the cheese. From a physical point of view, using Fick's model is not ideal in that case, but it was used because of its simplicity in the experimental and mathematical works [19]. Generally, for highly dissociable solutes such as $\mathrm{NaCl}$ and $\mathrm{KCl}$, the cross diffusion coefficients are smaller than the main ones [25].
Consequently, the main effective diffusion coefficients of $\mathrm{NaCl}$ and $\mathrm{KCl}$ were much larger $\left(\sim 4 \times 10^{-10} \mathrm{~m}^{2} \cdot \mathrm{s}^{-1}\right)$ than the cross diffusion coefficients between $\mathrm{NaCl}$ and $\mathrm{KCl}\left(\sim 0.1 \times 10^{-10} \mathrm{~m}^{2} \cdot \mathrm{s}^{-1}\right)$ in the semihard cheese type. Zorrilla and Rubiolo [88-90] observed that main diffusion coefficients of both $\mathrm{NaCl}$ and $\mathrm{KCl}$ were very similar because of their chemical similarities.

Gerla and Rubiolo [25] also studied multicomponent mass transport of lactic acid and $\mathrm{NaCl}$ in a solid-liquid system through the brining process of Pategras cheese. This was done to predict changes in acid concentration during the salting process. The $\mathrm{NaCl}$ diffusion rate was independent from the lactic acid concentration gradient, while the lactic acid diffusion rate increased 12 times due to $\mathrm{NaCl}$ concentration changes in the cheese. Therefore, in processes involving the simultaneous diffusion of several solutes, the largest solute gradient can cause the modifications of the diffusion properties of minor solutes. If these solutes are important for ripening, the modifications of their diffusion properties can have consequences on the sensorial properties of the cheese. These results established the importance of using multicomponent mass transport models. However, interactions between protons, $\mathrm{Na}^{+}$and $\mathrm{Cl}^{-}$ions within cheese matrices can be explained by other arguments than the magnitude of their gradients since they can all interact with the proteinic network. In that case, $\mathrm{Na}^{+}$and $\mathrm{Cl}^{-}$probably modify electrical charges of proteins and thus their buffering capacity, which in turn affect lactic acid diffusion properties.

Simal et al. [70] and Bona et al. [9, 10] described a mathematical procedure to obtain the diffusion coefficients of different species (salt and water) that simultaneously diffuse in cheese in such a situation that each mass flux is affected by the existence of the others. The correspondent local mass balances combined with Fick's law were simultaneously solved in one dimension [70] or in three dimensions using a numerical finite 
difference method $[9,10]$. Indeed, with the development of high-performance computers, it is possible to simulate a process close to reality using three-dimensional geometries and numerical techniques such as the finite element method (FEM) [9, 10]. Water losses and salt gain during brining could be adequately simulated using the proposed model. Although the experimental data of water and salt contents were in good agreement with calculated values, the main drawback of the proposed model was the high number of unknown parameters that had to be numerically identified.

The multicomponent analysis of mass transfer phenomena is an alternative to the classical modelling method presented in the Section 4.2.3. However, it was previously reported that from a physical point of view, the use of Fick's model may give misleading results when the Fickian analysis is applied in a complex system like food products. Indeed, the simplifications imposed on the model may affect its accuracy. Alternative methods described by irreversible thermodynamics and the StefanMaxwell theory have then come into force. In these approaches, the driving force is the chemical potential.

\subsection{Stefan-Maxwell approach}

Payne and Morison [61] developed a Stefan-Maxwell multicomponent approach to model salt and water diffusion in cheese. Stefan-Maxwell's model expresses the chemical gradient of potential like a linear function of the matter flux. A full description of this equation is given by [73]:

$$
\frac{x_{i}}{R T}\left(\frac{\partial \mu_{i}}{\partial x}\right)=\sum_{j=1}^{n} \frac{x_{i} x_{j}}{D_{i j}^{\mathrm{SM}}}\left(v_{j}-v_{i}\right),
$$

where $D_{i j}^{\mathrm{SM}}$ are the Stefan-Maxwell diffusion coefficients between components $i$ and $j\left(\mathrm{~m}^{2} \cdot \mathrm{s}^{-1}\right), R$ is the ideal gas constant, $8.31414 \mathrm{~J} \cdot \mathrm{mol}^{-1} \cdot \mathrm{K}^{-1}, T$ is the temperature
(K), $x_{i}, \mu_{i}$ and $v_{i}$ are respectively the molar fraction, the molar chemical potential $\left(\mathrm{J} \cdot \mathrm{mol}^{-1}\right)$ and velocity relative to stationary coordinates $\left(\mathrm{m} \cdot \mathrm{s}^{-1}\right)$, of the component $i$.

Payne and Morison [61] considered cheese as a three-component system consisting of $\mathrm{NaCl}$ (component 1), water (component 2) and a matrix of protein and fat (component 3).

In regard to the Fickian approach, the main advantage of Stefan-Maxwell equation is that no reference species is needed. Secondly, as corrections for thermodynamic non-ideality are included in this analysis, the concentration dependence of StefanMaxwell diffusion coefficients is not as strong as that of Fickian diffusion coefficients. In the case of dilute gases, the Stefan-Maxwell diffusion coefficients correspond to the binary values (Fickian diffusion coefficients). However, when applied to concentrated aqueous solutions or food matrices like cheese, the Stefan-Maxwell diffusion coefficients are no longer equal to the binary values.

For Payne and Morison [61], the main difficulties encountered with this model were the determination of water activity and the activity coefficient of salt in cheese. The value of cheese matrix activity was not required because it could be assumed that the diffusional flux of the matrix was insignificant. To solve the model, values for the Stefan-Maxwell diffusion coefficients between salt, water and the cheese matrix were required. However, there are very little data available in the literature for the StefanMaxwell diffusion coefficients, and none were found for cheese, salt and water. This does present a number of problems, the most significant being that the accuracy of the model is limited by the accuracy of these values [61]. Stefan-Maxwell diffusion coefficients are mainly determined empirically by doing a large number of assumptions. Payne and Morison [61] fitted experimental data from Geurts et al. [27] and Wesselingh et al. [84] to model 
Table II. Literature review of effective diffusion coefficients found for small solutes in different cheese types.

\begin{tabular}{|c|c|c|c|c|c|c|c|c|}
\hline \multirow[t]{2}{*}{ Cheese } & \multirow{2}{*}{$\begin{array}{c}\text { Composition } \\
\text { dry matter }(\mathrm{DM}) \\
\left(\mathrm{g} \cdot \mathrm{kg}^{-1}\right) \text {, fat/DM } \\
\left(\mathrm{g} \cdot 100 \mathrm{~g}^{-1}\right) \text { and } \mathrm{pH}\end{array}$} & \multicolumn{3}{|c|}{ Brining and/or ripening conditions } & \multirow[t]{2}{*}{ Geometry } & \multirow[t]{2}{*}{ Model } & \multirow{2}{*}{$\begin{array}{c}\text { Effective } \\
\text { diffusion } \\
\text { coefficient }\left(D_{\text {eff }}\right) \\
\left(\times 10^{-10} \mathrm{~m}^{2} \cdot \mathrm{s}^{-1}\right)\end{array}$} & \multirow[t]{2}{*}{ Refs. } \\
\hline & & $\begin{array}{c}\text { Process } \\
\text { considered }\end{array}$ & $\begin{array}{c}\text { Temperature } \\
\left({ }^{\circ} \mathrm{C}\right)\end{array}$ & $\begin{array}{c}\text { Brine } \\
\text { composition }\end{array}$ & & & & \\
\hline $\begin{array}{l}\text { Solute: } \mathrm{NaCl} \\
\text { Camembert } \\
\text { (soft-type } \\
\text { cheese) }\end{array}$ & $\begin{array}{c}\text { DM } 410 \\
\text { fat/DM } 45\end{array}$ & $\begin{array}{l}\text { Brining and } \\
\text { ripening }\end{array}$ & 14 & $\begin{array}{c}300 \mathrm{~g} \cdot \mathrm{kg}^{-1} \mathrm{NaCl} \\
\mathrm{pH} 4.6\end{array}$ & Slab & Fick (1D) & $\sim 2.54$ & [41] \\
\hline $\begin{array}{l}\text { Cuartirolo } \\
\text { Argentino } \\
\text { (soft-type } \\
\text { cheese) }\end{array}$ & $\begin{array}{c}\text { DM } 480 \\
\text { fat/DM } 51.7\end{array}$ & $\begin{array}{l}\text { Brining and } \\
\text { ripening }\end{array}$ & 7.5 & $\begin{array}{l}205 \mathrm{~g} \cdot \mathrm{kg}^{-1} \mathrm{NaCl} \\
\text { agitated or brine at rest }\end{array}$ & $\begin{array}{l}\text { Finite rigid } \\
\text { slab }\end{array}$ & Fick (1D) & 3.6 & {$[51,52]$} \\
\hline Feta & $\begin{array}{l}\text { DM } 440 \\
\text { fat/DM } 43\end{array}$ & Dry-salted & 13 & - & $\begin{array}{l}\text { Semi-finite } \\
\text { geometry }\end{array}$ & Fick (1D) & 2.3 & [87] \\
\hline $\begin{array}{l}\text { White cheese } \\
\text { (semi-hard, } \\
\text { Turkey) }\end{array}$ & $\begin{array}{c}\mathrm{DM} 450 \\
\text { fat/DM } 42 \\
\text { pH } 5.3\end{array}$ & Brining & $\begin{array}{l}4,12.5 \\
\text { and } 20\end{array}$ & $\begin{array}{c}150-200 \mathrm{~g} \cdot \mathrm{kg}^{-1} \\
\mathrm{NaCl}\end{array}$ & Finite slab & Fick (1D) & $\begin{array}{l}2.1,3 \text { and } 4 \\
\text { (no effect } \\
\text { of brine } \\
\text { concentration) }\end{array}$ & [74] \\
\hline $\begin{array}{l}\text { White cheese } \\
\text { (semi-hard, } \\
\text { Turkey) }\end{array}$ & $\begin{array}{c}\mathrm{DM} 450 \\
\text { fat/DM } 42 \\
\mathrm{pH} 5.3\end{array}$ & Brining & $4-20$ & $\begin{array}{c}150-200 \mathrm{~g} \cdot \mathrm{kg}^{-1} \\
\mathrm{NaCl}\end{array}$ & Finite slab & Fick (1D) & $2.2-4.2$ & {$[75]$} \\
\hline $\begin{array}{l}\text { Prato cheese } \\
\text { (semi-hard, } \\
\text { Brazil) }\end{array}$ & $\begin{array}{c}\text { DM } 517 \\
\text { fat/DM } 53 \\
\text { pH } 5.2\end{array}$ & Brining & 10 & $\begin{array}{c}150,200 \text { and } \\
250 \mathrm{~g} \cdot \mathrm{kg}^{-1} \\
\mathrm{NaCl}\end{array}$ & Parallelepiped & $\begin{array}{c}\text { Fick (3D) } \\
\text { and neural network }\end{array}$ & $\begin{array}{l}1.64,4.25 \\
\text { and } 3\end{array}$ & [7] \\
\hline $\begin{array}{l}\text { Romano } \\
\text { (hard-type } \\
\text { cheese) }\end{array}$ & $\begin{array}{c}\text { DM } 535 \\
\text { fat/DM } 38\end{array}$ & Brining & 20 & $\begin{array}{l}160 \mathrm{~g} \cdot \mathrm{kg}^{-1} \\
\mathrm{NaCl}\end{array}$ & Slab & Fick (1D) & $2.54-3.35$ & [35] \\
\hline
\end{tabular}


Table II. Continued.

\begin{tabular}{|c|c|c|c|c|c|c|c|c|}
\hline \multirow[t]{2}{*}{ Cheese } & \multirow{2}{*}{$\begin{array}{c}\text { Composition } \\
\text { dry matter }(\mathrm{DM}) \\
\left(\mathrm{g} \cdot \mathrm{kg}^{-1}\right) \text {, fat/DM } \\
\left(\mathrm{g} \cdot 100 \mathrm{~g}^{-1}\right) \text { and } \mathrm{pH}\end{array}$} & \multicolumn{3}{|c|}{ Brining and/or ripening conditions } & \multirow[t]{2}{*}{ Geometry } & \multirow[t]{2}{*}{ Model } & \multirow{2}{*}{$\begin{array}{c}\text { Effective } \\
\text { diffusion } \\
\text { coefficient }\left(D_{\text {eff }}\right) \\
\left(\times 10^{-10} \mathrm{~m}^{2} \cdot \mathrm{s}^{-1}\right) \\
\end{array}$} & \multirow[t]{2}{*}{ Refs } \\
\hline & & $\begin{array}{l}\text { Process } \\
\text { considered }\end{array}$ & $\begin{array}{c}\text { Temperature } \\
\left({ }^{\circ} \mathrm{C}\right)\end{array}$ & $\begin{array}{c}\text { Brine } \\
\text { composition }\end{array}$ & & & & \\
\hline $\begin{array}{l}\text { Sbrinz } \\
\text { (hard-type } \\
\text { cheese) }\end{array}$ & $\begin{array}{c}\text { DM } 650 \\
\text { fat/DM } 48\end{array}$ & $\begin{array}{l}\text { Brining and } \\
\text { ripening }\end{array}$ & $\begin{array}{c}\text { Brining at } 12{ }^{\circ} \mathrm{C} \\
(4 \text { days) and } \\
\text { diffusion at } \\
7,11,15 \\
\text { and } 20{ }^{\circ} \mathrm{C}\end{array}$ & $\begin{array}{c}200 \mathrm{~g} \cdot \mathrm{kg}^{-1} \\
\mathrm{NaCl}\end{array}$ & $\begin{array}{l}\text { Touching } \\
\text { semi-infinite } \\
\text { cylinders } \\
\text { (after the } \\
\text { brining step) }\end{array}$ & Fick (1D) & $\begin{array}{c}1.06( \pm 0.15) \text { to } \\
1.88( \pm 0.27) \\
\text { (temp. coef.: } 0.063 \\
\left.\times 10^{-10} \mathrm{~m}^{2} \cdot \mathrm{s}^{-1} \cdot{ }^{\circ} \mathrm{C}^{-1}\right)\end{array}$ & [29] \\
\hline $\begin{array}{l}\text { Cheddar } \\
\text { (hard-type } \\
\text { cheese) }\end{array}$ & DM 650 & Ripening & 10 & - & Slab & Fick (1D) & 1.16 & [86] \\
\hline $\begin{array}{l}\text { Emmental } \\
\text { (hard-type } \\
\text { cheese) }\end{array}$ & $\begin{array}{c}\text { DM } 600 \\
\text { fat/DM } 48\end{array}$ & Brining & $4-18$ & $\begin{array}{c}250 \mathrm{~g} \cdot \mathrm{kg}^{-1} \mathrm{NaCl} \\
0.3 \mathrm{~g} \cdot \mathrm{kg}^{-1} \mathrm{CaCl}_{2} \\
\mathrm{pH} 5.4\end{array}$ & $\begin{array}{l}\text { Infinite } \\
\text { cylinder }\end{array}$ & Fick (1D) & $0.62-2.22$ & [60] \\
\hline $\begin{array}{l}\text { Model } \\
\text { cheese } \\
\text { (Gouda style) }\end{array}$ & $\begin{array}{l}\text { DM } 580-630 \\
\text { fat } / D M \sim 50\end{array}$ & $\begin{array}{l}\text { Ripening } \\
\text { RH } 87 \%\end{array}$ & 13 & - & Slab & Fick (1D) & 2.3 & {$[28$} \\
\hline $\begin{array}{l}\text { Model } \\
\text { cheese } \\
\text { (Gouda style) }\end{array}$ & $\begin{array}{l}\text { DM } 533,566 \\
\text { and } 638 \\
\text { fat/DM } 62, \\
50,22 \text { and } 12 \\
\text { pH } 4.9-5.6\end{array}$ & Brining & 12.6 & $\begin{array}{c}130-310 \mathrm{~g} \cdot \mathrm{kg}^{-1} \\
\mathrm{NaCl} \\
15 \mathrm{~g} \cdot \mathrm{kg}^{-1} \mathrm{CaCl}_{2}\end{array}$ & $\begin{array}{l}\text { Flat } \\
\text { cylindrical } \\
\text { shape }\end{array}$ & Fick (1D) & $\begin{array}{c}\sim 2.3 \\
1.16-3.24 \\
\text { (temp. coef.: } 0.12 \\
\times 10^{-10} \mathrm{~m}^{2} \cdot \mathrm{s}^{-1} \cdot{ }^{\circ} \mathrm{C}^{-1} \text { ) }\end{array}$ & {$[26]$} \\
\hline $\begin{array}{l}\text { Model } \\
\text { cheese }\end{array}$ & $\begin{array}{c}\text { DM } 370 \text { and } 440 \\
\text { fat/DM } 20 \text { and } 40 \\
\text { pH } 6.2 \text { and } 6.5 \\
0.5 \text { and } \\
1.5 \mathrm{~g} \cdot 100 \mathrm{~g}^{-1} \mathrm{NaCl}\end{array}$ & $\begin{array}{l}\text { Release of } \\
\mathrm{NaCl} \text { from } \\
\text { the cheese } \\
\text { into water }\end{array}$ & $\begin{array}{l}13 \\
15\end{array}$ & $\begin{array}{l}\text { Water } \\
\text { Artificial } \\
\text { saliva }\end{array}$ & $\begin{array}{l}\text { Infinite } \\
\text { cylinder }\end{array}$ & $\begin{array}{l}\text { Fick (1D) } \\
\text { Fick (1D) }\end{array}$ & $\begin{array}{c}2.74-5.1 \\
( \pm 0.01) \\
2.81-3.43\end{array}$ & [46] \\
\hline
\end{tabular}


Table II. Continued.

\begin{tabular}{|c|c|c|c|c|c|c|c|c|}
\hline \multirow[t]{2}{*}{ Cheese } & \multirow{2}{*}{$\begin{array}{c}\text { Composition } \\
\text { dry matter }(\mathrm{DM}) \\
\left(\mathrm{g} \cdot \mathrm{kg}^{-1}\right) \text {, fat/DM } \\
\left(\mathrm{g} \cdot 100 \mathrm{~g}^{-1}\right) \text { and } \mathrm{pH}\end{array}$} & \multicolumn{3}{|c|}{ Brining and/or ripening conditions } & \multirow[t]{2}{*}{ Geometry } & \multirow[t]{2}{*}{ Model } & \multirow{2}{*}{$\begin{array}{c}\text { Effective } \\
\text { diffusion } \\
\text { coefficient }\left(D_{\text {eff }}\right) \\
\left(\times 10^{-10} \mathrm{~m}^{2} \cdot \mathrm{s}^{-1}\right)\end{array}$} & \multirow[t]{2}{*}{ Refs. } \\
\hline & & $\begin{array}{l}\text { Process } \\
\text { considered }\end{array}$ & $\begin{array}{c}\text { Temperature } \\
\left({ }^{\circ} \mathrm{C}\right)\end{array}$ & $\begin{array}{c}\text { Brine } \\
\text { composition }\end{array}$ & & & & \\
\hline $\begin{array}{l}\text { Solute: } \text { water } \\
\text { White cheese } \\
\text { (semi-hard, } \\
\text { Turkey) }\end{array}$ & $\begin{array}{c}\mathrm{DM} 450 \\
\text { fat/DM } 42 \\
\mathrm{pH} 5.3\end{array}$ & Brining & $\begin{array}{c}4,12.5 \text { and } \\
20\end{array}$ & $\begin{array}{c}150-200 \mathrm{~g} \cdot \mathrm{kg}^{-1} \\
\mathrm{NaCl}\end{array}$ & Finite slab & Fick (1D) & $\begin{array}{c}15 \% \text { brine: } \\
1.96-3.64 ; \\
20 \% \text { brine: } \\
1.69-3.09\end{array}$ & [76] \\
\hline \multicolumn{9}{|c|}{ Solutes: $\mathrm{NaCl}$ and water } \\
\hline $\begin{array}{l}\text { Fresh cheese } \\
\text { Pasteurized cow } \\
\text { and goat milk }\end{array}$ & No data & Brining & 5,15 and 20 & $\begin{array}{c}280 \mathrm{~g} \cdot \mathrm{L}^{-1} \mathrm{NaCl} \\
15 \mathrm{~g} \cdot \mathrm{L}^{-1} \mathrm{CaCl}_{2}\end{array}$ & $\begin{array}{c}\text { Cylinder } \\
\text { and parallelepiped }\end{array}$ & Fick (1D) & $\begin{array}{l}\text { Water: } 5.71 \text {, } \\
8.83 \text { and } 9.99 \text {; } \\
\mathrm{NaCl}: 3.56 \text {, } \\
8.26 \text { and } 9.17\end{array}$ & {$[70]$} \\
\hline $\begin{array}{l}\text { Mahon cheese } \\
\text { (soft-type } \\
\text { cheese, Spain) }\end{array}$ & DM 244 & $\begin{array}{l}\text { Ripening } \\
\text { RH 85\% }\end{array}$ & 12 & $\begin{array}{c}280 \mathrm{~g} \cdot \mathrm{L}^{-1} \mathrm{NaCl} \\
15 \mathrm{~g} \cdot \mathrm{L}^{-1} \mathrm{CaCl}_{2}\end{array}$ & Parallelepiped & Fick (3D) & $\begin{array}{l}\text { Water: 0.078; } \\
\text { NaCl: } 5.3\end{array}$ & [71] \\
\hline $\begin{array}{l}\text { Gouda } \\
\text { (semi-hard } \\
\text { cheese) }\end{array}$ & $\begin{array}{c}\text { DM } 565 \\
\text { fat/DM } 53\end{array}$ & Brining & 20 & $170 \mathrm{~g} \cdot \mathrm{kg}^{-1} \mathrm{NaCl}$ & Slab & $\begin{array}{l}\text { Maxwell- } \\
\text { Stefan } \\
\text { (1D) }\end{array}$ & $\begin{array}{c}D_{\text {salt }- \text { chesse }}^{\mathrm{SM}}= \\
0.0027-0.014 \\
\text { from the core to } \\
\text { the edge of } \\
\text { the cheese }\end{array}$ & {$[61]$} \\
\hline \multicolumn{9}{|c|}{ Solutes: $\mathrm{NaCl}$ and $\mathrm{KCl}$} \\
\hline $\begin{array}{l}\text { Fynbo cheese } \\
\text { (semi-hard, } \\
\text { Turkey) }\end{array}$ & $\begin{array}{c}\text { DM } 470 \\
\text { fat/DM } 29.6-36.2\end{array}$ & Brining & 12 & $\begin{array}{l}100 \mathrm{~g} \cdot \mathrm{L}^{-1} \mathrm{NaCl} \\
100 \mathrm{~g} \cdot \mathrm{L}^{-1} \mathrm{KCl} \\
15 \mathrm{~g} \cdot \mathrm{L}^{-1} \mathrm{CaCl}_{2}\end{array}$ & $\begin{array}{l}\text { Diffusion } \\
\text { cell }\end{array}$ & Fick (1D) & $\begin{array}{c}\mathrm{NaCl}: 4.14 ; \\
\mathrm{KCl}: 3.91\end{array}$ & [89] \\
\hline $\begin{array}{l}\text { Prato cheese } \\
\text { (semi-hard, } \\
\text { Brazil) }\end{array}$ & $\begin{array}{c}\text { DM } 540 \\
\text { fat/DM } 52.8\end{array}$ & Brining & 10 & $\begin{array}{c}146 \mathrm{~g} \cdot \mathrm{L}^{-1} \mathrm{NaCl} \\
50.6 \mathrm{~g} \cdot \mathrm{L}^{-1} \mathrm{KCl} \\
5 \mathrm{~g} \cdot \mathrm{L}^{-1} \mathrm{CaCl}_{2}\end{array}$ & Parallelepiped & Fick (1D) & $\begin{array}{l}\mathrm{NaCl}: 2.6 \text {; } \\
\mathrm{KCl}: 2.77\end{array}$ & [8] \\
\hline
\end{tabular}


Table II. Continued.

\begin{tabular}{|c|c|c|c|c|c|c|c|c|}
\hline \multirow[t]{2}{*}{ Cheese } & \multirow{2}{*}{$\begin{array}{c}\text { Composition } \\
\text { dry matter }(\mathrm{DM}) \\
\left(\mathrm{g} \cdot \mathrm{kg}^{-1}\right), \text { fat } / \mathrm{DM} \\
\left(\mathrm{g} \cdot 100 \mathrm{~g}^{-1}\right) \text { and } \mathrm{pH}\end{array}$} & \multicolumn{3}{|c|}{ Brining and/or ripening conditions } & \multirow[t]{2}{*}{ Geometry } & \multirow[t]{2}{*}{ Model } & \multirow{2}{*}{$\begin{array}{c}\text { Effective } \\
\text { diffusion } \\
\text { coefficient }\left(D_{\text {eff }}\right) \\
\left(\times 10^{-10} \mathrm{~m}^{2} \cdot \mathrm{s}^{-1}\right)\end{array}$} & \multirow[t]{2}{*}{ Refs. } \\
\hline & & $\begin{array}{l}\text { Process } \\
\text { considered }\end{array}$ & $\begin{array}{c}\text { Temperature } \\
\left({ }^{\circ} \mathrm{C}\right)\end{array}$ & $\begin{array}{c}\text { Brine } \\
\text { composition }\end{array}$ & & & & \\
\hline $\begin{array}{l}\text { Prato cheese } \\
\text { (semi-hard, } \\
\text { Brazil) }\end{array}$ & $\begin{array}{c}\text { DM } 540 \\
\text { fat/DM } 52.8\end{array}$ & Brining & 10 & $\begin{array}{c}146 \mathrm{~g} \cdot \mathrm{L}^{-1} \mathrm{NaCl} \\
50.6 \mathrm{~g} \cdot \mathrm{L}^{-1} \mathrm{KCl} \\
5 \mathrm{~g} \cdot \mathrm{L}^{-1} \mathrm{CaCl}_{2}\end{array}$ & Parallelepiped & Fick (3D) & $\begin{array}{l}\mathrm{NaCl}: 2.8 ; \\
\mathrm{KCl}: 2.94\end{array}$ & {$[10]$} \\
\hline \multicolumn{9}{|l|}{ Other solutes } \\
\hline $\begin{array}{l}\text { Lactose in small } \\
\text { curd cottage } \\
\text { cheese }\end{array}$ & $\begin{array}{l}\text { No available } \\
\text { information }\end{array}$ & Washing & 25 & $\begin{array}{l}\text { Demineralized } \\
\text { water } \mathrm{pH} 4.5 \\
\quad\left(\mathrm{H}_{3} \mathrm{PO}_{4}\right)\end{array}$ & Sphere & Fick (1D) & 3.8 & [11] \\
\hline $\begin{array}{l}\text { Lactose in } \\
\text { Skimmed } \\
\text { Quark cheese } \\
\text { (Soft-type } \\
\text { cheese, } \\
\text { Germany) }\end{array}$ & $\begin{array}{l}\text { No available } \\
\text { information }\end{array}$ & - & 4 & - & $\begin{array}{l}\text { Touching } \\
\text { semi-infinite } \\
\text { cylinders }\end{array}$ & Fick (1D) & $\begin{array}{c}1.37 \\
( \pm 0.13)\end{array}$ & [85] \\
\hline $\begin{array}{l}\text { Sucrose } \\
\text { in milk }\end{array}$ & Fat $15 \mathrm{~g} \cdot \mathrm{kg}^{-1}$ & $\begin{array}{c}\text { Contact } \\
\text { with } \\
15 \mathrm{~g} \cdot 100 \mathrm{~g}^{-1} \\
\text { agar gel }\end{array}$ & $\begin{array}{c}20-24 \\
\text { (room } \\
\text { temperature) }\end{array}$ & - & $\begin{array}{l}\text { Touching } \\
\text { semi-infinite } \\
\text { cylinders }\end{array}$ & Fick (1D) & $\begin{array}{c}\text { Initial gel } \\
\text { sucrose } \\
\text { concentration } \\
C_{\mathrm{s} 0} 787 \mathrm{~g} \cdot \mathrm{L}^{-1}: 1.9, \\
C_{\mathrm{s} 0} 515 \mathrm{~g} \cdot \mathrm{L}^{-1}: 2.6, \\
C_{\mathrm{s} 0} 279 \mathrm{~g} \cdot \mathrm{L}^{-1}: 3.9\end{array}$ & [81] \\
\hline $\begin{array}{l}\text { Lactic acid } \\
\text { and } \mathrm{NaCl} \\
\text { in Pategras }\end{array}$ & $\begin{array}{l}\text { DM } 544 \\
\text { fat/DM } 43 \\
\text { Lactic acid } \\
13 \mathrm{~g} \cdot \mathrm{kg}^{-1}\end{array}$ & $\begin{array}{l}\text { Ripening } \\
\text { RH } 90 \%\end{array}$ & 13 & $\begin{array}{c}200 \mathrm{~g} \cdot \mathrm{kg}^{-1} \mathrm{NaCl} \\
5 \mathrm{~g} \cdot \mathrm{kg}^{-1} \mathrm{CaCl}_{2}\end{array}$ & Finite slab & $\begin{array}{l}\text { Fick (1D) } \\
\text { multicomponent } \\
\text { diffusion }\end{array}$ & $\begin{array}{c}\mathrm{NaCl}: 3.2 \\
\text { lactic acid: } \sim 1\end{array}$ & {$[25]$} \\
\hline
\end{tabular}


Table II. Continued.

\begin{tabular}{|c|c|c|c|c|c|c|c|c|}
\hline \multirow[t]{2}{*}{ Cheese } & \multirow{2}{*}{$\begin{array}{c}\text { Composition } \\
\text { dry matter }(\mathrm{DM}) \\
\left(\mathrm{g} \cdot \mathrm{kg}^{-1}\right) \text {, fat/DM } \\
\left(\mathrm{g} \cdot 100 \mathrm{~g}^{-1}\right) \text { and } \mathrm{pH}\end{array}$} & \multicolumn{3}{|c|}{ Brining and/or ripening conditions } & \multirow[t]{2}{*}{ Geometry } & \multirow[t]{2}{*}{ Model } & \multirow{2}{*}{$\begin{array}{c}\text { Effective } \\
\text { diffusion } \\
\text { coefficient }\left(D_{\text {eff }}\right) \\
\left(\times 10^{-10} \mathrm{~m}^{2} \cdot \mathrm{s}^{-1}\right) \\
\end{array}$} & \multirow[t]{2}{*}{ Refs. } \\
\hline & & $\begin{array}{l}\text { Process } \\
\text { considered }\end{array}$ & $\begin{array}{c}\text { Temperature } \\
\left({ }^{\circ} \mathrm{C}\right)\end{array}$ & $\begin{array}{c}\text { Brine } \\
\text { composition }\end{array}$ & & & & \\
\hline $\begin{array}{l}\text { Potassium } \\
\text { sorbate in } \\
\text { American } \\
\text { processed cheese }\end{array}$ & $\begin{array}{c}\text { DM } 600 \\
\text { fat/DM } 45\end{array}$ & Brining & $\begin{array}{c}\text { Room } \\
\text { temperature }\end{array}$ & $\begin{array}{l}250 \mathrm{~g} \cdot \mathrm{L}^{-1} \\
\text { potassium } \\
\text { sorbate } \\
\text { solutions }\end{array}$ & $\begin{array}{c}\text { Cubes } \\
\text { (finite slab) }\end{array}$ & Fick (1D) & 1.31 & {$[40]$} \\
\hline $\begin{array}{l}\text { Potassium sorbate } \\
\text { in Mozzarella }\end{array}$ & $\begin{array}{l}\mathrm{DM} \sim 500 \\
\text { fat } / \mathrm{DM} 45\end{array}$ & & & & & & 0.674 & \\
\hline $\begin{array}{l}\text { Aroma compounds } \\
\text { in model cheese: } \\
\text { diacetyl, } \\
\text { heptan-2-one, } \\
\text { and ethyl hexanoate }\end{array}$ & $\begin{array}{c}\text { DM } 370 \\
\text { fat/DM } 20 \text { and } 40 \\
\text { pH } 6.2 \\
1.5 \mathrm{~g} \cdot 100 \mathrm{~g}^{-1} \mathrm{NaCl}\end{array}$ & $\begin{array}{l}\text { Release of } \\
\text { aroma } \\
\text { compounds } \\
\text { in the air }\end{array}$ & 13 & - & VASK & Fick (1D) & $\begin{array}{c}\text { Diacetyl: } 0.04 ; \\
\text { heptan-2-one: } \\
0.2-0.12 ; \\
\text { ethyl hexanoate: } \\
0.18-0.07\end{array}$ & {$[47]$} \\
\hline
\end{tabular}


the Stefan-Maxwell diffusion coefficients. The model successfully predicted independent shrinkage arising from an excess of outgoing diffusion of water over the incoming diffusion of salt. Their model also indicated that there was a large interaction between salt and the cheese matrix, which caused a significant reduction in the diffusion of salt into cheese. Further work is required to interpret the Stefan-Maxwell diffusion coefficients from a physical point of view.

\section{CHARACTERISTIC VALUES OF EFFECTIVE DIFFUSION COEFFICIENTS IN CHEESE}

Extensive data on diffusion coefficients in cheese are available in the literature, but cover a large range of values. This is undoubtedly due to the complexity and diversity in cheese structure and composition. This variability depends on the cheese type and origin, as well as on various methods of determination which are not always fully explicit, nor justified [50].

\subsection{Salt and moisture transfer}

Most of the published studies concerning mass transfer phenomena during cheese production deal with the salting and ripening processes. After moulding, cheese is placed in brine and a net movement of $\mathrm{Na}^{+}$and $\mathrm{Cl}^{-}$ions, from the brine into the cheese, results from the osmotic pressure difference between the cheese moisture and the brine. Consequently, moisture diffuses throughout the cheese matrix to restore osmotic pressure equilibrium [34]. The amount of salt retained and water removed from the cheese depend, mostly, on brine concentration and brining time [32]. Salt diffusive migration in cheese usually occurs slowly. For example, salt equilibration times for cheese range from about 1-2 weeks in soft cheese to several months in semi-hard cheese type. In Parmesan cheese, which represents an extreme case, salt equilibrium is only attained after about 10 months [64]. For the controlled manufacture of these products, it is therefore important to know the factors influencing salt penetration and to be able to predict the diffusion rates. This implies the knowledge of the apparent diffusion coefficient of salt and its dependence on factors such as temperature and brine concentration.

Water and $\mathrm{NaCl}$ diffusion transport processes in and out of the cheese matrix during classical brining and ripening are most of the time described using the second Fick's law, considering the diffusion coefficient as constant. This diffusion coefficient represents the $\mathrm{NaCl}$ effective diffusion coefficient when considering the cheese matrix and $\mathrm{NaCl}$ as the two components of the binary diffusion system [52]. For $\mathrm{NaCl}$, the effective diffusion coefficient $D_{\text {eff }}$ varies from $1-5.5 \times 10^{-10} \mathrm{~m}^{2} \cdot \mathrm{s}^{-1}$ depending on cheese, compared to $1.16 \times 10^{-9} \mathrm{~m}^{2} \cdot \mathrm{s}^{-1}$ for the diffusion coefficient of $\mathrm{NaCl}$ in pure water at temperatures around $12.5^{\circ} \mathrm{C}$ (Tab. II). Temperature has a strong effect on the effective diffusion coefficient of $\mathrm{NaCl}$ in some cheese types, which can increase up to $9.2 \times 10^{-10} \mathrm{~m}^{2} \cdot \mathrm{s}^{-1}$ at $20{ }^{\circ} \mathrm{C}$ during the brining of Fresh cheese [70].

This increase was attributed by Geurts et al. [27] to an increase in true diffusion and to some effect on diffusion-interfering factors. For them, the temperature increase could lead to a possible decrease in the viscosity of the cheese moisture fraction and to a modification of the amount of proteinbound water, which could result in an increase of the relative pore width of the protein matrix. The acceleration of the mass transfer rate with the temperature is not so important in semi-hard and hard-type cheeses, with effective diffusion coefficients up to $2-4 \times 10^{-10} \mathrm{~m}^{2} \cdot \mathrm{s}^{-1}$ at $20^{\circ} \mathrm{C}$ in cheese like Romano [35], White cheese [75], Sbrinz [29] or Emmental [60]. Indeed, moisture content is much inferior in 


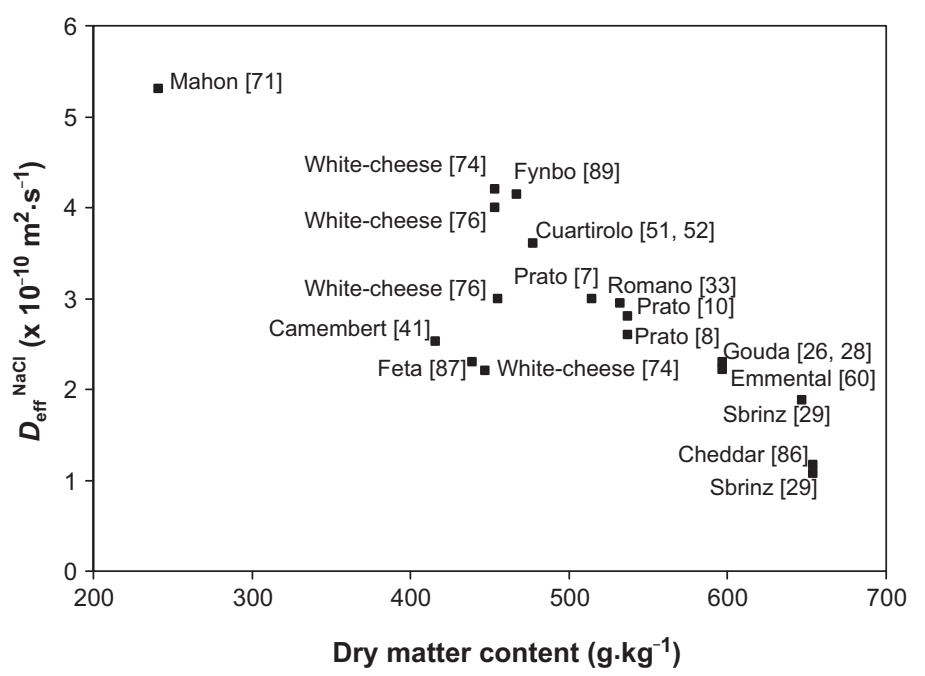

Figure 2. Effective diffusion coefficient of salt versus dry matter content in different cheese types.

semi-hard and hard-type cheeses than in soft- or fresh-type cheeses. Diffusion-interfering effects, which mainly depend on water and protein-bound contents, are then probably much less marked in hard-type cheeses than in soft-type cheeses when the temperature increases.

The factors affecting the rate of salt diffusion in cheese during salting have already been investigated in detail by Geurts et al. [27], Guinee [31, 32] and Guinee and Fox [33-37]. These factors are (i) the concentration gradient across the different zones of cheese, which has a major effect on the level of salt absorption by a cheese during salting, but scarcely affects the rate of salt diffusion; (ii) the ripening temperature and (iii) the cheese composition (fat, protein and moisture). It is difficult to establish the individual effect of each component on the salt diffusion rate because strong interactions exist between them, depending on the cheese microstructure. Data on $\mathrm{NaCl}$ effective diffusion coefficients reported on Table II were subjected to statistical analysis by the multiple linear regression (MLR) procedure in Excel $^{\circledR}$. MLR analysis provides an equation that can be used to predict $D_{\text {eff }}$ of salt in cheese matrices, function of parameters such as composition (dry matter (DM) and fat on dry matter ratio (Fat/DM)), temperature $(T)$ and brine composition if available. Each parameter was first centred and reduced to minimize the impact of data order of magnitude. The best equation obtained for $D_{\text {eff }}$ of salt was

$$
\begin{aligned}
D_{\text {eff }}= & 3.39-1.25 \times \mathrm{DM}+0.24 \\
& \times \text { fat } / \mathrm{DM}-0.14 \times T .
\end{aligned}
$$

A highly significant $(P<0.001)$ coefficient of multiple determination $\left(R^{2}\right)$ of 0.75 for this model indicated that $D_{\text {eff }}$ can be estimated using these parameters. Fat/ DM, $T$ and brine composition parameters were not significant $(P<0.1)$. DM was the only significant parameter $(P<0.001)$, meaning that effective diffusion coefficients of salt solutes can be accurately predicted in cheese matrices knowing their dry matter composition (Fig. 2).

Floury et al. [23] and Lauverjat [46] were first to study the release of salt in the mouth during food chewing according to 
the composition of model cheese matrices. The release of salt from the cheese into artificial saliva was mathematically modelled as an effective diffusion process with Fick's second law. The variation in the effective diffusion coefficient of salt according to the cheese matrix compositions was linked to their structural and textural properties. Effective diffusion coefficients were included between 2.7 and $5.1 \times 10^{-10} \mathrm{~m}^{2} \cdot \mathrm{s}^{-1}$ at $13-15{ }^{\circ} \mathrm{C}$ depending on the matrix composition (Tab. II). These values were of the same order of magnitude as published diffusion coefficients that were measured during the brining of real cheeses of same dry matter and fat content (Fig. 2).

Table II shows that literature on water diffusion in cheese during brining and ripening is not so abundant. Effective moisture diffusion coefficients in cheese have been reported by Luna and Chavez [53] for Gouda cheese, Turhan and Gunasekaran [75] for White cheese and Simal et al. [69, 70] for Mahon and Fresh cheeses. During the salting of cheese in brine, salt and moisture gradients develop from the surface to the core [53]. The ripening process implies water losses due to dehydration of the cheese and salt migration to achieve an almost uniform salt distribution, which is an important factor in cheese ripening [90]. Notice that the values of effective diffusion coefficients of water considerably vary depending on cheese type, and more particularly on the experimental method that was employed to model moisture transfer (Tab. II). It is then difficult to link those values to cheese composition.

During the brining and ripening of cheese, not only is the water content in cheese reduced and the salt concentration increased but, for example, the lactic acid concentration is also modified. Detection of lactic acid in the brine proves that this solute is able to diffuse from the cheese into the brine [48]. Other solutes than salt and water, like lactic acid or small peptides for example, are of crucial importance for the final quality of the cheese and its preservation.
However, diffusion properties of those components were almost not modelled. In the following paragraphs, we give a complete review of the mass transfer properties of these other small solutes in cheese matrices, like lactose, additives and metabolites.

\subsection{Transfer of other solutes}

Publications concerning the diffusion of small solutes in cheese matrices, except from salt and moisture, are scarce (Tab. II). They deal with the diffusion of whey components such as lactose or sucrose [11, 81, 85], lactic acid [25] and potassium sorbate [40]. One recent study also deals with the diffusion properties of aroma compounds in model cheese matrices of different compositions [47]. Only one research team has published results about mass transfer phenomena of metabolites resulting from biological activities in cheese during brining or ripening [2-4, 72].

\subsubsection{Transfer of whey components}

Warin et al. [81] modelled the effective diffusion coefficient of sugar in agar gel/ milk bilayer system in order to mimic the sucrose and lactose transfer between a dairy product and a fruit layer. The system was modelled with a liquid milk phase on the top of a gel containing agar, citric acid and different concentrations of sucrose. Average disaccharide concentrations at different locations were determined for the system after different diffusion times. Average disaccharide concentrations in each slice of agar gel were deduced from total solids after subtracting agar content and from total solids after subtracting protein and fat contents in the milk phase. Experimental data were fitted to Fick's second law with separate effective diffusion coefficients of sugar in the milk and in the agar gel phases. As sucrose and lactose have the same molecular weight and a similar structure, the authors made the hypothesis that their diffusion properties 
were identical. Experimental values of effective diffusion coefficients in milk and agar gel obtained at room temperature $\left(22^{\circ} \mathrm{C}\right)$ were compared to a correlation reported by Hallström et al. [39] for sucrose diffusivity concentration dependence in aqueous solution at the same temperature:

$$
\log D_{\mathrm{s}}=-8.271-9.2 x_{\mathrm{s}},
$$

with $D_{\mathrm{s}}$ the effective diffusion coefficient of lactose and sucrose $\left(\mathrm{m}^{2} \cdot \mathrm{s}^{-1}\right)$ and $x_{\mathrm{s}}$ the mole fraction of sucrose. For Warin et al. [81], as the effective diffusivity of sucrose in the agar gel and milk phases could be estimated using a correlation usually employed for the calculation of diffusion coefficients in aqueous solutions, there was neither exclusion effect due to the porosity of the agar phase, nor obstruction effect due to tortuosity of the gel, on the disaccharide diffusion properties. This confirms results showing an effective diffusion coefficient of sucrose in $1.5 \%$ agar membranes identical to that in water [49]. With regard to the milk phase, similarly, they concluded that there were no exclusion or obstruction effects of milk proteins on the effective diffusion coefficient of disaccharide solutes.

This study led to interesting results with regard to mass transfer properties of sugar in liquid and low-concentrated matrices. However, it gave no information on effective coefficients of such solutes in structured solid matrices like cheeses.

Bressan et al. [11] modelled the diffusion of whey components (rich in lactose) from small curd cottage cheese particles during their washing process. They considered the diffusion of solutes as isothermal $\left(25^{\circ} \mathrm{C}\right)$ in a porous network with several refinements to account for the whey on curd surfaces. Three geometrical approximations (slab, cube and sphere) for small curd cottage cheese particles were examined using Fick's second law. It was assumed that there was no chemical reaction in the system and no convective mass transfer in the pores. The term "whey components" was used by the authors to take solutes from low molecular salts to whey proteins into account in the model. One solution to the problem of presenting all solids in a single pseudocomponent was to use a lumped parameter model [6]. The model also included a correction for the whey introduced into the washing system on the surface of the curd or entrained among cheese particles.

Bressan et al. [11] concluded that diffusion from a spherical cheese particle considering whey entrained in curd interstices by capillary forces was an acceptable basis for a mass transfer model. According to them, the model yielded to an effective diffusion coefficient of expected magnitude for lactose, i.e. $3-4 \times 10^{-10} \mathrm{~m}^{2} \cdot \mathrm{s}^{-\mathrm{P}}$ at $25^{\circ} \mathrm{C}$ (Tab. II). The diffusion coefficient of lactose at infinite dilution in water at $25^{\circ} \mathrm{C}$ is $5.2 \times 10^{-10} \mathrm{~m}^{2} \cdot \mathrm{s}^{-1}$ [54]. The effective lactose diffusion coefficient in the cheese is smaller than the value for infinitely diluted solution, mainly due to the sterical hindrance to the random movement of lactose by the cheese matrix.

Wilde et al. [85] have also studied matrix effects on the diffusion rates of lactose in a soft-type cheese (Quark cheese) and several milk acid gels of different dry matter contents. A two-chamber diffusion tube was used to determine the effective diffusion coefficient of lactose. The product enriched with lactose was introduced into one of the two cylinders and the product with the original lactose content into the other to ensure the concentration difference required for diffusion. The concentration of the diffusing lactose was measured in each slice of $1 \mathrm{~mm}$ thickness using both a high pressure liquid chromatography (HPLC) analysis and enzymatic test kits. The model of onedimensional infinite media with a constant cross-section based on Fick's second law of diffusion for time-dependent diffusion process was verified with regard to the effective diffusion coefficient of lactose 
in viscous milk products. The effective diffusion coefficient $D_{\text {eff }}$ obtained from lactose concentration profiles at $4{ }^{\circ} \mathrm{C}$ in skimmed Quark cheese (dry matter $180 \mathrm{~g} \cdot \mathrm{kg}^{-1}$ ) was $1.37 \pm 0.13 \times 10^{-10} \mathrm{~m}^{2} \cdot \mathrm{s}^{-1}$. In the milk acid gels, $D_{\text {eff }}$ showed a linear decline from 1.7 to $0.3 \times 10^{-10} \mathrm{~m}^{2} \cdot \mathrm{s}^{-1}$ as the dry matter of the product increased from 110 to $210 \mathrm{~g} \cdot \mathrm{kg}^{-1}$. The effective lactose diffusion coefficient in skimmed Quark cheese was higher than the value observed in milk acid gels with the same dry matter content $\left(180 \mathrm{~g} \cdot \mathrm{kg}^{-1}\right)$. Indeed, Quark cheese is a suspension of coagulated casein particles that are dispersed in a milk whey phase. Lactose diffusion may then mainly take place in the liquid whey phase. Pure diffusion of lactose molecules here is probably slowed down by the dispersed casein particles. Indeed, the structure of milk acid gels gets built up directly in the chamber, resulting in a homogeneous protein network that causes a higher diffusion resistance for lactose molecules. For Wilde et al. [85], the slope of the straight line could characterize the matrix resistance to lactose diffusion.

Although these studies revealed interesting results on the diffusion properties of lactose in dairy matrices, we are still quite far from the microstructure of traditional cheeses from soft- to hard-type cheeses for which dry matter contents are superior to $350 \mathrm{~g} \cdot \mathrm{kg}^{-1}$. We could not find any published studies concerning lactose diffusion in such solid matrices.

\subsubsection{Transfer of food additives}

Potassium sorbate is widely used in processed cheese as a natural preservative. Effective diffusion coefficient of potassium sorbate in American processed and Mozzarella cheeses was determined by Han and Floros [40]. American processed cheese is an emulsion of ingredients such as milk, whey, milk fat, milk protein concentrate, whey protein concentrate and salt, which does not meet the legal definition of cheese itself. American processed cheese and Mozzarella cheeses had a maximum moisture of 400 and $480-510 \mathrm{~g} \cdot \mathrm{kg}^{-1}$ and a minimum milk fat of 270 and 39$42 \mathrm{~g} \cdot \mathrm{kg}^{-1}$. To determine the effective diffusion coefficient $D_{\text {eff }}$, the concentration of potassium sorbate in sliced cheese was measured as a function of the distance from the cheese surface. $D_{\text {eff }}$ was calculated by nonlinear regression with experimental data based on Fick's second law. $D_{\text {eff }}$ of potassium sorbate through American processed cheese was $1.31 \times 10^{-10} \mathrm{~m}^{2} \cdot \mathrm{s}^{-1}$ and for Mozzarella cheese $6.74 \times 10^{-11} \mathrm{~m}^{2} \cdot \mathrm{s}^{-1}$. American processed cheese, because of a higher ratio of moisture-to-fat than the one of Mozzarella cheese (Tab. II), enables the fastest diffusion of water-soluble components. For Han and Floros [40], knowledge of the effective diffusion coefficient of potassium sorbate allows one to accurately estimate the concentration of this preservative agent inside and at the surface, function of time. It will then be possible to predict the preservation time of the product, which corresponds to a residual concentration of potassium sorbate above the critical fungistatic level inside and at the surface of the product [40].

\subsubsection{Transfer of aroma compounds}

Lauverjat et al. [47] estimated the effective diffusion coefficients of three aroma compounds (diacetyl, heptan-2-one and ethyl hexanoate) in model cheese differing by their composition (Tab. II). They tested two experimental methods: the classical diffusion cell method and the volatile air stripping kinetic (VASK) method. The VASK method is based on the measurement of the aroma compound's gaseous concentration above a layer of product when a gaseous flow rate is applied. Aroma compound's concentration is then measured in-line using a high sensitivity proton transfer reactionmass spectrometer. This method is much faster than the classical diffusion cell method, 
but it is dedicated to the volatile compounds released from the product. Comparing the values obtained for two model cheeses differing by their fat on dry matter ratios, the known effect of fat content on aroma mobility was mainly observed for the two hydrophobic compounds (heptan-2-one and ethyl hexanoate). When the fat on dry matter content increased from $20 \%$ to $40 \%$, the effective diffusion coefficients showed a $45 \%$ decrease for heptan-2-one and a 60\% decrease for ethyl hexanoate (Tab. II).

\subsubsection{Transfer of metabolites}

Aldarf et al. [2], Stephan et al. [71], Aldarf et al. [3] and Amrane et al. [4] modelled - independently - the diffusion of lactate, glutamate and ammonium in relation either to the growth of Geotrichum candidum or to the growth of Penicillium camembertii at the surface of model matrix (agarose) simulating Camembert cheese. The main purpose of these papers was to study the mechanisms of diffusion and to propose a theoretical approach that could be subsequently applied to curd during ripening for its monitoring and control. The assimilation of lactic acid by $G$. candidum (and $P$. camembertii) growing at the surface of the curd induced a concentration gradient, which results in the diffusion of this metabolite from the core to the rind. In a similar way, ammonium production at the surface of the curd induced a diffusion of this metabolite from the rind to the core. These diffusion mechanisms appeared therefore as the main factors in soft cheese ripening.

These authors developed a diffusion/reaction model in which the diffusion of lactic acid from the bottom of the gel to the upper surface, or that of glutamate and ammonium from the upper surface to the bottom of the gel, is induced by their respective consumption and production at the surface of the gel due to fungal growth. Growth kinetics were described using the widespread Verlhust model [58], and both substrate consumption and ammonium production were considered to be linked to growth. The experimental diffusion gradients of substrates (lactate and glutamate) and ammonium recorded during G. candidum growth were fitted to the Fick's second law using Crank's solution [17]. Effective diffusion coefficients were deduced from the experimental concentration gradients. Values of $4.63 \pm 0.34 \times 10^{-10} \mathrm{~m}^{2} \cdot \mathrm{s}^{-1}$ for lactate, $6.48 \times 10^{-10} \mathrm{~m}^{2} \cdot \mathrm{s}^{-1}$ for glutamate and $9.26 \pm 0.58 \times 10^{-10} \mathrm{~m}^{2} \cdot \mathrm{s}^{-1}$ for ammonium were found, regardless of the $\mathrm{pH}$ of the experiment. For lactate and ammonium components, the effective diffusion coefficients found in $2 \%$ agarose were, respectively, $57 \%$ and $64 \%$ of their value in pure water.

This result clearly showed that agarose gel slowed down the diffusion rates of lactate and ammonium components. The diffusion/ reaction model fitted with the experimental data until the end of growth, except with regard to ammonium concentration gradients during $G$. candidum growth on peptonelactate-based medium. Of course, the diffusion/reaction model has to be considered as a preliminary step, which has to be followed by a similar work on real dairy model media, more precisely a lactic curd, in order to better understand the mechanism of curd neutralization, responsible for the development of texture.

\section{ALTERNATIVE METHODS APPLICABLE TO CHEESE}

Concentration profiles can also be considered on a microscopic scale using a representative molecule, or probe molecule, which can be easily characterized using a specific technique [15]. Recent advances in non-invasive, continuous techniques of measurement, e.g. magnetic resonance imaging (MRI), NMR or FRAP, now allow the use of higher space and time resolutions (Tab. I). Indeed, using radioactively labelled or fluorescent molecules, it is possible to measure the rate 
of diffusion of one component in a multicomponent system. What is involved is an interchange of labelled and unlabelled molecules, while the total amount of that molecule, labelled and unlabelled, is constant throughout the system [15]. The transport of molecules is essentially caused by intermolecular collisions (Brownian motions). As a consequence, no mass flow occurs and a diffusion coefficient called "self-diffusion coefficient" is measured [18].

\subsection{Nuclear magnetic resonance}

The pulsed field gradient NMR (PFGNMR) technique is a powerful tool that can be used to measure polymer self-diffusion coefficients in suspensions and gels. It is a non-destructive and non-invasive way to measure the self-diffusion coefficient of small molecules by detecting the proton mobility [16]. In a PFG-NMR experiment, the observation time can vary from few milliseconds up to several seconds. Depending on the observation time, the magnitude of the diffusion coefficients obtained at different observation scales enables one to discriminate the different transport mechanisms. For example, if the self-diffusion is independent of the observation time for a porous system, then the system exhibits no restriction to diffusion.

In 1983, Callaghan et al. [13] compared water self-diffusion in Cheddar and Swisstype cheeses. Their results have shown that water molecules were not confined in water droplets, but had the freedom to move over distances much longer than the fat droplet sizes. The magnitude of the diffusion coefficients was consistent with a migration along the surface of the protein chains. According to Mariette et al. [55], water diffusion in casein systems can be explained by two diffusion pathways: one around and the other through the casein micelles. The obstruction effect on water diffusion was related to local restrictions at the casein micelle surface and explained the absence of any effect of casein gelation by rennet. Moreover, Metais et al. [56] showed that the water self-diffusion coefficients in casein matrices could not be simply explained by the water content only. When caseins, fat globules and soluble fractions are mixed in order to obtain cheese models, the effect of each constituent should be determined to accurately explain the water self-diffusion. They also showed that the two obstruction effects, relative to fat globules and casein micelles, seemed to be independent. This result was in agreement with the observation of Geurts et al. [27], despite the fact that the measurement methods and the diffusing molecules considered were different.

Colsenet et al. [16] used PFG-NMR spectroscopy to study the diffusion of molecular probes (polyethylene glycols (PEG)) in casein suspensions and casein gels, in order to determine the effects of probe molecular size, casein concentrations and rennet coagulation. A more complex behaviour was observed for PEG molecules than for water. First of all, a strong dependency of diffusion on probe size was observed, both in casein suspensions and in casein gels: as the PEG size increased, the self-diffusion coefficient was reduced. This effect was more pronounced for high casein concentrations than for low casein concentrations: the larger the PEG size, the greater the obstruction to diffusion. Second, the formation of a rennet gel resulted in an enhanced self-diffusion coefficient for the largest probes.

The main drawback of this technique is the high cost of the material. Its main difficulty for the scientists is to establish the physical link between this self-diffusion coefficient measured by PFG-NMR and the values of the effective diffusion coefficient estimated in complex matrices with more classical methods. Moreover, it is restricted to the study of mass transfer phenomena of solutes which present spectral properties easily discernable from spectral data of the matrix components. The application of this 
technique to solutes like small peptides or proteins naturally present in cheese is thus hardly possible.

\subsection{Magnetic resonance imaging}

Other promising non-destructive approach to measure diffusion properties of salt and water in food products is MRI.

${ }^{23} \mathrm{Na}-\mathrm{MRI}$ is based on the paramagnetic properties of the naturally occurring ${ }^{23} \mathrm{Na}$ isotope, which makes it detectable in strong magnetic fields [79]. Within the past decade, ${ }^{23} \mathrm{Na}-\mathrm{MRI}$ has proved to be a reliable method for quantitative and qualitative assessment of salt in various foods such as fermented soy paste (Miso), pickled cucumbers and plum seeds [42], snow crab [59] and pork meat $[30,63]$. Besides being non-destructive, this method has the advantage of being easily supplemented by other relevant measurements such as sodium profiles and diffusion-weighted imaging, simply by changing the acquisition parameters. Diffusion-weighted imaging allows the visualization of changes in microscopic water molecule motion (Brownian motion) and quantitative measures of diffusion properties of water in food structures like muscle tissues [79]. For Vestergaard et al. [78], the ${ }^{23} \mathrm{Na}$-MRI methodology is still under intense investigation around the world because the problem of sodium being partly "invisible" (a certain percentage of the $\mathrm{Na}^{+}$is not detected) has not been solved yet.

MRI has also been used to visualize water distribution in one, two or three directions during the drying, rehydration, freezing and thawing of various fruits and vegetables $[65,66]$. Indeed, loss of proton mobility during phase transitions results in a decrease in signal intensity. Kuo et al. [45] applied this technique to study the formation of ice during freezing of pasta filata and non-pasta filata Mozzarella cheeses, the spatial redistribution of water $T_{2}$ relaxation time and the changes of water self-diffusion coefficient within unfrozen and frozen-stored cheese samples. Images of water spin number density and water $T_{2}$ relaxation time were obtained using spin-echo imaging pulse sequence. The water self-diffusion coefficient was measured by PFG spin-echo technique. They measured a significant change in $T_{2}$ and $D$ values of water following freezing-thawing. The $D$ values of the frozenstored pasta filata Mozzarella cheese samples were higher than those for the unfrozen samples. Such a difference was not observed for the non-pasta filata Mozzarella cheese samples. These results were attributed to the microstructure differences between the two cheeses.

Despite the advantage of being a very precise non-destructive analytical technique, MRI presents some inherent difficulties, like a complex calibration and data handling work, errors in the determination of the physical boundaries and possible low signal-to-noise ratios [24]. Moreover, the conventional MRI techniques are typically designed for component with high molecular mobility, for which the water $T_{2}$ relaxation times are rather long ( $>\mathrm{ms})$. Such techniques are then insensitive to molecules with low mobility, for which the transverse relaxation times are very short $(<\mathrm{ms})$. Therefore, limitations of conventional MRI have hampered its application to a major class of food systems, i.e., where mobility of water is restricted because of its strong association with the matrix [62].

\subsection{Fluorescence recovery after photobleaching}

Within the last 30 years, FRAP has become an important and versatile technique to study the dynamics in various systems, such as living cells, membranes and other biological environments [14]. In polymer physics, the photobleaching methods are employed to investigate diffusion in macromolecular systems, particularly in networks. Although the technique is relatively old, its application to study endogenous 
intracellular proteins in living cells is relatively recent [14]. A review of the fundamentals of FRAP and several examples of its applications is given by Meyvis et al. [57]. Its principle is to irreversibly photobleach a certain region within a fluorescently labelled sample by irradiation with a short intense light pulse. Immediately after bleaching, a highly attenuated light beam is used to measure the recovery of fluorescence inside the bleached area as a result of diffusional exchange of bleached fluorophores by unbleached molecules from the surroundings. The analysis of this process yields information about the diffusion coefficient and the fraction of mobile species.

In a common FRAP experiment, only the rate of recovery of the fluorescence intensity within some preselected area is measured. Performing the experiment in a confocal laser scanning microscope (CLSM) reveals the same information with high spatial resolution [68]. To measure the mobility of a fluorescent molecule such as green fluorescent protein, images of the fluorescently labelled cell are collected over time, while the fluorescent and photobleached molecules redistribute until equilibrium is reached. By plotting the relationship between fluorescence intensity and time, the mobility of the fluorescent proteins can be directly measured [14]. The most commonly used approach to describe the mobility of molecules during FRAP experiments is to assume the spatiotemporal dynamics of these molecules to be diffusive in nature. Under this assumption, the kinetic parameter that measures the rate of movement is the effective diffusion coefficient, determined with Fick's diffusion model. This microscopic, non-destructive and slightly invasive technique, in which the probe concentration remains micromolar, originates from mobility studies in biological membranes [5]. It was then extended to other fields, mostly for liquid or highly hydrated systems, in which diffusion follows the Stokes-Einstein law [44]. It covers a wide range of apparent diffusion coefficients, from $10^{-20}$ to $10^{-9} \mathrm{~m}^{2} \cdot \mathrm{s}^{-1}$ [43].

In spite of its interest and its simplicity to be implemented, the FRAP technique has not been used yet for the determination of solute diffusion coefficients in dairy matrices. Indeed, to be able to use this method, the migrating molecule has to be fluorescent or labelled with a fluorescent probe. This is not the case of small solutes such as $\mathrm{NaCl}$ or water. For bigger molecules, it is necessary to find a fluorescent probe with a great affinity for the diffusing solute to be labelled or with similar size and physicochemical properties in order to simulate the targeted molecule. Moreover, this method seems difficult to adapt to complex and opaque matrices like cheese.

\section{CONCLUSION}

Mass transfer of solutes in cheese is essential for the ripening process and the final quality of the cheese. Numerous studies have been reported on the transfer of salt in different cheese types during the brining and ripening processes. Some of them also take the simultaneous counterflow of water into account, even if modelling moisture transfer seemed to be more complicated. Effective diffusion coefficients of salt and moisture in different cheese types and compositions have been reported in this review. Regardless of the cheese origin, its type (soft, semi-hard or hard) and its composition (dry matter, fat and $\mathrm{pH}$ ), the effective diffusion coefficients of salt ranged between 1 and $5.3 \times$ $10^{-10} \mathrm{~m}^{2} \cdot \mathrm{s}^{-1}$ at around $10-15^{\circ} \mathrm{C}$. A significant linear relationship between dry matter content of the matrix and effective diffusion coefficient of salt was statistically observed. However, these values should be considered cautiously because their comparison is difficult. Indeed, there are very large discrepancies of approaches used to determine solute mass transfer properties and of 
the experimental conditions employed. For example, if diffusion properties are obtained using the concentration profile method with an invasive method to follow the migrating molecule concentration, spatial resolution is generally quite low and the results are not precise enough.

Very few papers are dealing with the mass transfer properties of other small solutes in cheese. However, modelling the effective diffusion coefficient of cheese minor components, such as lactose and biological metabolites, substrates and products of the enzymatic activity of immobilized colonies, seems essential for the control and the optimization of cheese ripening. Indeed, migration rates of those solutes are probably the limiting step during the ripening stage. The knowledge of the migration rates appears to be essential for the full understanding of cheese ripening.

Alternative methods considered as nondestructive, such as MRI, NMR or FRAP techniques, are currently developed to measure the self-diffusion coefficient of solutes in heterogeneous matrices. Thanks to their high space resolution, these techniques make it possible to obtain concentration profiles of the migrating solute with a good precision and to avoid problems due to sample variability. However, they are still difficult to apply to complex and heterogeneous media like cheese (Tab. I). Further research is necessary to adapt those promising methods to the determination of mass transfer properties of a wide variety of small solutes in complex heterogeneous matrices like cheese or other real food media.

\section{REFERENCES}

[1] Aguilera J.M., Why food microstructure? J. Food Eng. 67 (2005) 3-11.

[2] Aldarf M., Fourcade F., Amrane A., Prigent Y., Diffusion of lactate and ammonium in relation to growth of Geotrichum candidum at the surface of solid media, Biotechnol. Bioeng. 87 (2004) 69-80.
[3] Aldarf M., Fourcade F., Amrane A., Prigent Y., Substrate and metabolite diffusion within model medium for soft cheese in relation to growth of Penicillium camembertii, J. Ind. Microbiol. Biotechnol. 33 (2006) 685-692.

[4] Amrane A., Aldarf M., Fourcade F., Prigent Y., Substrate and metabolite diffusion within solid medium in relation to growth of Geotrichum candidum, in: FOODSIM 2006, 4th International Conference Simulation Modelling in the Food and Bio Industry, Naples, Italy, June 15-17, 2006, pp. 179186.

[5] Axelrod D., Koppel D.E., Schlessinger J., Elson E., Webb W., Mobility measurement by analysis of fluorescence photobleaching recovery kinetics, Biophys. J. 16 (1976) 1055-1069.

[6] Bailey J.E., Diffusion of grouped multicomponent mixtures in uniform and nonuniform media, Aiche J. 21 (1975) 192-194.

[7] Baroni A.F., Menezes M.R., Adell E.A.A., Ribeiro E.P., Modeling of Prato cheese salting: fickian and neural network approaches, in: Welti-Chanes J., Velez-Ruiz J.F., Barbosa-Canovas G.V. (Eds.), Transport Phenomena in Food Processing, CRC Press, Boca Raton, USA, 2003, pp. 192-212.

[8] Bona E., Borsato D., da Silva R.S.S.F., Silva L.H.M., Multicomponent diffusion during simultaneous brining of Prato Brazilian cheese, Cienc. Tecnol. Aliment. 25 (2005) 394-400.

[9] Bona E., Carneiro R.L., Borsato D., da Silva R.S.S.F., Fidelis D.A.S., Silva L.H.M., Simulation of $\mathrm{NaCl}$ and $\mathrm{KCl}$ mass transfer during salting of Prato cheese in brine with agitation: a numerical solution, Braz. J. Chem. Eng. 24 (2007) 337-349.

[10] Bona E., da Silva R.S.S.F., Borsato D., Silva L.H.M., Fidelis D.A.D., Multicomponent diffusion modeling and simulation in prato cheese salting using brine at rest: the finite element method approach, J. Food Eng. 79 (2007) 771-778.

[11] Bressan J.A., Carroad P.A., Merson R.L., Dunkley W.L., Modelling of isothermal diffusion of whey components from small curd cottage cheese during washing, J. Food Sci. 47 (1982) 84-88.

[12] Broyart B., Boudhrioua N., Bonazzi C., Daudin J.-D., Modelling of moisture and salt transport in gelatine gels during drying at constant temperature, J. Food Eng. 81 (2007) 657-671. 
[13] Callaghan P.T., Jolley K.W., Humphrey R.S., Diffusion of fat and water in cheese as studied by pulsed field gradient nuclear magnetic resonance, J. Colloid Interface Sci. 93 (1983) 521-529.

[14] Carreroa G., McDonald D., Crawford E., de Vries G., Hendzel M.J., Using FRAP and mathematical modelling to determine the in vivo kinetics of nuclear proteins, Methods 29 (2003) 14-28.

[15] Cayot N., Dury-Brun C., Karbowiak T., Savary G., Voilley A., Measurement of transport phenomena of volatile compounds: a review, Food Res. Int. 41 (2008) 349-362.

[16] Colsenet R., Soderman O., Mariette F., Effect of casein concentration in suspensions and gels on poly(ethylene glycol)s NMR selfdiffusion measurements, Macromolecules 38 (2005) 9171-9179.

[17] Crank J., The Mathematics of Diffusion, Oxford University Press, Oxford, UK, 1975.

[18] Crank J., Park G.S., Methods of measurement, in: Crank J., Park G.S. (Eds.), Diffusion in Polymers, Academic Press, Inc., London, UK, 1968, pp. 1-39.

[19] Cussler E.W., Diffusion: Mass Transfer in Fluid Systems, Cambridge University Press, Cambridge, UK, 1976.

[20] Djelveh G., Gros J.B., Bories B., An improvement of the cell diffusion method for the rapid determination of diffusion constants in gels or foods, J. Food Sci. 54 (1989) 166-169.

[21] Doulia D., Tzia K., Gekas V., A knowledge base for the apparent mass diffusion coefficient (D-eff) of foods, Int. J. Food Prop. 3 (2000) 1-14.

[22] Feunteun S., Mariette F., Impact of casein gel microstructure on self-diffusion coefficient of molecular probes measured by ${ }^{1} \mathrm{H}$ PFG-NMR, J. Agric. Food Chem. 55 (2007) 10764-10772.

[23] Floury J., Rouaud O., le Poullennec M., Famelart M.H., Reducing salt level in food. Part 2: Modelling salt diffusion in model cheese systems with regards to their composition, LWT-Food Sci. Technol. 42 (2009) 1621-1628.

[24] Frias J.M., Foucat L., Bimbenet J.J., Bonazzi C., Modeling of moisture profiles in paddy rice during drying mapped with magnetic resonance imaging, Chem. Eng. J. 86 (2002) 173-178.
[25] Gerla P.E., Rubiolo A.C., A model for determination of multicomponent diffusion coefficients in foods, J. Food Eng. 56 (2003) 401-410.

[26] Geurts T.G., Oortwijn H., Transport phenomena in butter, its relation to its structure, Neth. Milk Dairy J. 29 (1975) 253-262.

[27] Geurts T., Walstra P., Mulder H., Transport of salt and water during salting of cheese. I. Analysis of the processes involved, Neth. Milk Dairy J. 28 (1974) 102-129.

[28] Gomes A.M.P., Vieira M.M., Malcata F.X., Survival of probiotic microbial strains in a cheese matrix during ripening: simulation of rates of salt diffusion and microorganism survival, J. Food Eng. 36 (1998) 281-301.

[29] Gros J.B., Rüegg M., Determination of the apparent diffusion coefficient of sodium chloride in model foods and cheese, in: Jowitt R. (Ed.), Physical Properties of Foods, Vol. 2, Elsevier Applied Science, London, UK, 1987, pp. 71-108.

[30] Guiheneuf T.M., Gibbs S.J., Hall L.D., Measurement of the inter-diffusion of sodium ions during pork brining by one-dimensional ${ }^{23} \mathrm{Na}$ Magnetic Resonance Imaging (MRI), J. Food Eng. 31 (1997) 457-471.

[31] Guinee T.P., Studies on the movements of sodium chloride and water in cheese and the effects on cheese ripening, Ph.D. Thesis, National University of Ireland, Cork, 1985.

[32] Guinee T.P., Salting and the role of salt in cheese, Int. J. Dairy Technol. 57 (2004) 99-109.

[33] Guinee T.P., Fox P.F., Sodium-chloride and moisture changes in Romano-type cheese during salting, J. Dairy Res. 50 (1983) 511-518.

[34] Guinee T.P., Fox P.F., Influence of cheese geometry on the movement of sodiumchloride and water during brining, Ir. J. Food Sci. Technol. 10 (1986) 73-96.

[35] Guinee T.P., Fox P.F., Influence of cheese geometry on the movement of sodiumchloride and water during ripening, Ir. J. Food Sci. Technol. 10 (1986) 97-118.

[36] Guinee T.P., Fox P.F., Salt in Cheese: Physical, Chemical and Biological Aspects, in: Fox P.F. (Ed.), Cheese: Chemistry, Physics and Microbiology: General Aspects, Vol. 1, Chapman \& Hall, London, UK, 1993, pp. 257-302.

[37] Guinee T.P., Fox P.F., Salt in cheese: physical, chemical and biological aspects, in: Fox P.F., 
McSweeney P.L.H., Cogan T.M., Guinee T.P. (Eds.), Cheese: Chemistry, Physics and Microbiology: General Aspects, Vol. 1, Elsevier Applied Science, London, UK, 2004, pp. 207-259.

[38] Gutenwik J., Nilsson B., Axelsson A., Determination of protein diffusion coefficients in agarose gel with a diffusion cell, Biochem. Eng. J. 19 (2009) 1-7.

[39] Hallström B., Skjöldebrand C., Trägardh C., Heat transfer and food products, in: Handbook of Chemistry and Physics, Elsevier Applied Science, London, UK, 1988, pp. 1-29.

[40] Han J.H., Floros J.D., Potassium sorbate diffusivity in American processed and Mozzarella cheeses, J. Food Sci. 63 (1998) 435-437.

[41] Hardy J., Étude de la diffusion du sel dans les fromages à pâte molle de type camembert. Comparaison du salage à sec et du salage en saumure, Ph.D. Thesis, Université Nancy 1, France, 1976.

[42] Ishida N., Kobayashi T., Kano H., Nagai S., Ogawa H., Na-23-NMR imaging of foods, Agric. Biol. Chem. 55 (1991) 2195-2200.

[43] Karbowiak T., Hervet H., Leger L., Champion D., Debeaufort F., Voilley A., Effect of plasticizers (water and glycerol) on the diffusion of a small molecule in iotacarrageenan biopolymer films for edible coating application, Biomacromolecules 7 (2006) 2011-2019.

[44] Kovaleski J.M., Wirth M.J., Applications of fluorescence recovery after photobleaching, Anal. Chem. 69 (1997) 600-605.

[45] Kuo M.I., Anderson M., Gunasekaran S., Determining effects of freezing on pasta filata and non-pasta filata Mozzarella cheeses by nuclear magnetic resonance imaging, J. Dairy Sci. 86 (2003) 2525-2536.

[46] Lauverjat C., Compréhension des mécanismes impliqués dans la mobilité et la libération du sel et des composés d'arôme et leur rôle dans la perception. Cas de matrices fromagères modèles, Ph.D. Thesis, AgroParisTech, France, 2009.

[47] Lauverjat C., de Loubens C., Déléris I., Tréléa I.C., Souchon I., Rapid determination of partition and diffusion properties for salt and aroma compounds in complex food matrices, J. Food Eng. 4 (2009) 407-415.

[48] Lawrence R.C., Gilles J., Factors that determine the $\mathrm{pH}$ of young Cheddar cheese, N. Z. J. Dairy Sci. Technol. 17 (1982) 1-14.
[49] Lebrun L., Junter G.A., Diffusion of sucrose and dextran through agar-gel membranes, Enzym. Microb. Technol. 15 (1993) 10571062.

[50] Lucas T., Bohuon Ph., Model-free estimation of mass-fluxes based on concentration profiles. I. Presentation of the method and of a sensitivity analysis, J. Food Eng. 70 (2005) 129-137.

[51] Luna J.A., Bressan J.A., Mass-transfer during brining of Cuartirolo Argentino cheese, J. Food Sci. 51 (1986) 829-831.

[52] Luna J.A., Bressan J.A., Mass-transfer during ripening of Cuartirolo Argentino cheese, J. Food Sci. 52 (1987) 308-311.

[53] Luna J.A., Chavez M.S., Mathematicalmodel for water diffusion during brining of hard and semi-hard cheese, J. Food Sci. 57 (1992) 55-58.

[54] Mammarella E.J., Rubiolo A.C., Predicting the packed-bed reactor performance with immobilized microbial lactase, Process Biochem. 41 (2006) 1627-1636.

[55] Mariette F., Topgaard D., Jonsson B., Soderman O., 1H NMR diffusometry study of water in casein dispersions and gels, J. Agric. Food Chem. 50 (2002) 4295-4302.

[56] Metais A., Cambert M., Riaublanc A., Mariette F., Effects of casein and fat content on water self-diffusion coefficients in casein systems: a pulsed field gradient nuclear magnetic resonance study, J. Agric. Food Chem. 52 (2004) 3988-3995.

[57] Meyvis T.K.L., De Smedt S.C., Van Oostveldt P., Demeester J., Fluorescence recovery after photobleaching: a versatile tool for mobility and interaction measurements in pharmaceutical research, Pharm. Res. 16 (1999) 1153-1162.

[58] Moraine R.A., Rogovin P., Kinetics of polysaccharide B-1459 fermentation, Biotechnol. Bioeng. 8 (1996) 511-524.

[59] Nagata T., Chuda Y., Yan X., Suzuki M., Kawasaki K., The state analysis of $\mathrm{NaCl}$ in snow crab (Chionoecetes japonicus) meat examined by ${ }^{23} \mathrm{Na}$ and ${ }^{35} \mathrm{Cl}$ nuclear magnetic resonance (NMR) spectroscopy, J. Sci. Food Agric. 80 (2000) 1151-1154.

[60] Pajonk A.S., Saurel R., Andrieu J., Experimental study and modelling of effective $\mathrm{NaCl}$ diffusion coefficients values during Emmental cheese brining, J. Food Eng. 60 (2003) 307-313. 
[61] Payne M.R., Morison K.R., A multi-component approach to salt and water diffusion in cheese, Int. Dairy J. 9 (1999) 887-894.

[62] Ramos-Cabrer P., Van Duynhoven J.P.M., Timmer H., Nicolay K., Monitoring of moisture redistribution in multicomponent food systems by use of magnetic resonance imaging, J. Agric. Food Chem. 54 (2006) 672-677.

[63] Renou J.-P., Benderbous S., Bielicki G., Foucat L., Donnat J.-P., ${ }^{23} \mathrm{Na}$ magnetic resonance imaging: distribution of brine in muscle, MRI 12 (1994) 131-137.

[64] Resmini P., Volonterio G., Annibaldi S., Ferri G., Study of salt diffusion in Parmigiano-Reggiano cheese using $\mathrm{Na}^{36} \mathrm{Cl}$, Sci. Tec. Latt.-Casearia 25 (1974) 149-166.

[65] Ruiz-Cabrera M.A., Gou P., Foucat L., Renou J.P., Daudin J.D., Water transfer analysis in pork meat supported by NMR imaging, Meat Sci. 67 (2005) 169-178.

[66] Schwartzberg H.G., Chao R.Y., Solute diffusivities in leaching processes, Food Technol. 36 (1982) 73-86.

[67] Seiffert S., Oppermann W., Systematic evaluation of FRAP experiments performed in a confocal laser scanning microscope, J. Microsc. Oxford 220 (2005) 20-30.

[68] Sherwood T.G., Pigford R.L., Wilke C.R., Mass transfer, in: Clark B.J., Maisel J.W. (Eds.), McGraw-Hill Inc., New York, USA, 1975, pp. 39-43.

[69] Simal S., Sanchez E.S., Berna A., Mulet A., Simulation of counter-diffusional mass transfer, Chem. Eng. Commun. 189 (2002) 173-183.

[70] Simal S., Sanchez E.S., Bon J., Femenia A., Rossello C., Water and salt diffusion during cheese ripening: effect of the external and internal resistances to mass transfer, J. Food Eng. 48 (2001) 269-275.

[71] Stephan J., Couriol C., Fourcade F., Amrane A., Prigent Y., Diffusion of glutamic acid in relation to growth of Geotrichum candidum and Penicillium camembertii at the surface of a solid medium, J. Chem. Technol. Biotechnol. 79 (2004) 234-239.

[72] Takeuchi S., Maeda M., Gomi Y., Fukuoka M., Watanabe H., The change of moisture distribution in a rice grain during boiling as observed by NMR imaging, J. Food Eng. 33 (2008) 281-297.
[73] Taylor R., Krishna R., Multicomponent Mass Transfer, Wiley, New York, USA, 1993.

[74] Turhan M., Modelling of salt transfer in white cheese during short initial brining, Neth. Milk Dairy J. 50 (1996) 541-550.

[75] Turhan M., Gunasekaran S., Analysis of moisture transfer in White cheese during brining, Milchwissenschaft 54 (1999) 446-450.

[76] Turhan M., Kaletunc G., Modelling of salt diffusion in white cheese during long-term brining, J. Food Sci. 57 (1992) 1082-1085.

[77] Varzakas T.H., Leach G.C., Israilides C.J., Arapoglou D., Theoretical and experimental approaches towards the determination of solute effective diffusivities in foods, Enzym. Microb. Technol. 37 (2005) 29-41.

[78] Vestergaard C., Andersen B.L., AdlerNissen J., Sodium diffusion in cured pork determined by ${ }^{22} \mathrm{Na}$ radiology, Meat Sci. 76 (2007) 258-265.

[79] Vestergaard C., Risum J., Adler-Nissen J., ${ }^{23} \mathrm{Na}-\mathrm{MRI}$ quantification of sodium and water mobility in pork during brine curing, Meat Sci. 69 (2005) 663-672.

[80] Voilley A., Souchon I., Flavour retention and release from the food matrix: an overview, in: Voilley A., Etievant P. (Eds.), Flavour in Food, Woodhead Publishing Limited, Cambridge, UK, 2006, pp. 117-132.

[81] Warin F., Gekas V., Voirin A., Dejmek P., Sugar diffusivity in agar gel/milk bilayer systems, J. Food Sci. 62 (1997) 454-456.

[82] Welti-Chanes J., Mujica-Paz H., ValdezFragoso A., Leon-Cruz R., Fundamentals of Mass Transport, in: Welti-Chanes J., Vélez-Ruiz J.F., Barbosa-Cánovas G.V. (Eds.), Transport Phenomena in Food Processing, CRC Press, Boca Raton, USA, 2003, pp. 11-65.

[83] Wesselingh J.A., Krishna R., Mass Transfer in Multicomponent Mixtures, Delft University Press, Delft, Netherlands, 2000.

[84] Wesselingh J.A., Vonk P., Kraaijeveld G., Exploring the Maxwell-Stefan description of ion-exchange, Chem. Eng. J. Biochem. Eng. J. 57 (1995) 75-89.

[85] Wilde J., Baumgartner C., Fertsch B., Hinrichs J., Matrix effects on the kinetics of lactose hydrolysis in fermented and acidified milk products, Chem. Biochem. Eng. 15 (2001) 143-147. 
[86] Wiles P.G., Baldwin A.J., Dry salting of cheese, part I: Diffusion, Food Bioprod. Process. 74 (C3) (1996) 127-132.

[87] Yanniotis S., Anifantakis E., Diffusion of salt in dry-salted Feta cheese, in: Jowitt R., Escher F., Hallstrom B., Meffert H.F.T., Spiess W.E.L., Vos G. (Eds.), Physical Properties of Foods, Applied Science Publishers, London, UK, 1983.

[88] Zorrilla S.E., Rubiolo A.C., A model for using the diffusion cell in the determination of multicomponent diffusion-coefficients in gels or foods, Chem. Eng. Sci. 49 (1994) 2123-2128.

[89] Zorrilla S.E., Rubiolo A.C., Fynbo cheese $\mathrm{NaCl}$ and $\mathrm{KCl}$ changes during ripening, J. Food Sci. 59 (1994) 972-975.

[90] Zorrilla S.E., Rubiolo A.C., Modeling $\mathrm{NaCl}$ and $\mathrm{KCl}$ movement in Fynbo cheese during salting, J. Food Sci. 59 (1994) 976-980. 